\title{
Enhanced Photosynthesis and Carbon Metabolism Favor Arsenic Tolerance in Artemisia annua, a Medicinal Plant as Revealed by Homology-Based Proteomics
}

\author{
Rashmi Rai, ${ }^{1}$ Sarita Pandey, ${ }^{2}$ Alok Kumar Shrivastava, ${ }^{2}$ and Shashi Pandey Rai ${ }^{1}$ \\ ${ }^{1}$ Laboratory of Morphogenesis, Center of Advanced Study in Botany, Banaras Hindu University, Varanasi 221005, India \\ ${ }^{2}$ Laboratory of Algal Biology, Molecular Biology Section, Center of Advanced Study in Botany, Banaras Hindu University, \\ Varanasi 221005, India
}

Correspondence should be addressed to Shashi Pandey Rai; shashi.bhubotany@gmail.com

Received 19 October 2013; Accepted 3 February 2014; Published 29 April 2014

Academic Editor: David Sheehan

Copyright (C) 2014 Rashmi Rai et al. This is an open access article distributed under the Creative Commons Attribution License, which permits unrestricted use, distribution, and reproduction in any medium, provided the original work is properly cited.

\begin{abstract}
This paper provides the first proteomic evidence of arsenic (As) tolerance and interactive regulatory network between primary and secondary metabolism in the medicinal plant, Artemisia annua. While chlorophyll fluorescence and photosynthetic rate depicted mild inhibition, there was a significant enhancement in PSI activity, whole chain, ATP, and NADPH contents in $100 \mu \mathrm{M}$ As treatments compared to the control plants. However, a decrease in the above variables was recorded under $150 \mu \mathrm{M}$ treatments. Proteomic decoding of the survival strategy of A. annua under As stress using 2-DE followed by MALDI-MS/MS revealed a total of 46 differentially expressed protein spots. In contrast to other plants where As inhibits photosynthesis, A. annua showed appreciable photosynthetic $\mathrm{CO}_{2}$ assimilation and allocation of carbon resources at $100 \mu \mathrm{M}$ As concentration. While an increased accumulation of ATP synthase, ferredoxin-NADP $(\mathrm{H})$ oxidoreductase, and FeS-rieske proteins supported the operation of cyclic electron transport, mdr $\mathrm{ABC}$ transporter protein and pcs gene might be involved in As detoxification. The most interesting observation was an increased accumulation of $L E A F Y$ like novel protein conceivably responsible for an early onset of flowering in A. annua under As stress. This study not only affirmed the role of energy metabolism proteins but also identified potential candidates responsible for As tolerance in plants.
\end{abstract}

\section{Introduction}

In recent years, metal/metalloid contamination has resulted in degradation of large areas of cultivable lands, posing a serious threat to sustainable agriculture and food security in developing countries like India [1]. The frequent use of Asladen ground water for irrigation elevates As levels in the soils and makes land unproductive and toxic, thereby resulting in severe reduction of growth and yield of food crops [2,3]. This calls for judicious management of contaminated lands to put them back in cultivation. Although a number of As-tolerant noncommercial plants, including some species of the genera Pteris, Agrostis, Lepidium, Lemna, and Jasione, are known to accumulate high levels of As and have been successfully exploited for As phytoremediation $[4,5]$, none of these have any commercial use. Hence, it is highly desirable to identify nonedible plant species which may not only be cultivated for phytoremediation of As contaminated soils but also put back into commercial use.

Artemisia annua (Asteraceae) is an important dicotyledonous medicinal plant native from China and widely distributed in temperate and subtropical zones of the world, especially in Asia. It is a nonmodel plant with limited genomic information, although sequencing of limited number of randomly selected cDNA clones has been achieved [6]. Despite the above, this plant has provoked wide interest for biotechnological studies because it produces an antimalarial drug, called artemisinin. Currently, artemisinin and its semisynthetic derivatives are extensively used in the treatment of malaria, mostly in combination therapies [7], as well as in the treatment of cancers and viral diseases $[8,9]$. In addition to the therapeutic properties, $A$. annua possess 
important attributes such as a fast growth rate and a high biomass production, easy cultivation, and an unusual weedy habit, all of them important traits for plants employed for phytoextraction of metals and metalloids from contaminated soils [10]. Our previous study demonstrated a significant induction of artemisinin production under As stress. The high tolerance of $A$. annua against As stress was coupled with an appreciable increase in biomass and As accumulation capacity, thus enabling this plant to be worth cultivating in As contaminated soils [11].

The enhanced artemisinin production and As tolerance of $A$. annua raises the question as which proteins could be potentially responsible for the above traits and how far the changes in different metabolic pathways, that is, primary and secondary, are interrelated with each other. While some mechanisms including, surface exclusion, intracellular detoxification, efflux, and production of phytochelatins have been proposed for the development of As tolerance in plants [12], the molecular mechanism underlying physiological changes still remains to be elucidated. Since proteins are directly involved in stress responses, any change in biochemical and physiological parameters is likely to be reflected at the proteome level. Proteomics has become a useful tool to unravel the relationships between protein abundance and stress acclimation [13]. High resolution 2D-PAGE (2-DE) is the most direct approach for defining gene functions, and studies based on transcriptomics and proteomics can provide significant information on the processes involved in these stress responses [14].

Proteomics has been widely used to investigate the proteome of plants under abiotic stresses [15-17]. However, proteomic studies on As-induced changes are still few and limited to maize roots [18], maize shoots [19], rice roots [20], rice leaves [21], a pseudometallophyte Agrostis tenuis [22], and the hyperaccumulator species Pteris vittata fronds [23] and roots [24]. With the exceptions of Agrostis and Pteris, all the above mentioned proteomic investigations primarily focus on plants which are agronomically important food crops. It is worth mentioning that country like India, where food-security is of foremost concern, to use such plants for phytoremediation of As-contaminated agricultural lands cannot be acceptable. In view of the fact that none of above plant species is well adapted to high As concentrations, A. annua emerged as the plant of choice. Despite potential application and tolerance the proteome of A. annua has remained unexplored due to unsequenced genome and inadequate representation in annotated, nonredundant (nr) protein databases. This study is the first attempt to decode the As tolerance strategy of $A$. annua combining physiological and proteomic analyses and to establish interactive network between its primary and secondary metabolism.

It requires mentioning that As (V) exposure (i) triggers ROS production causing alterations in the antioxidant pathways [11, 20], (ii) disturbs phosphate metabolism (e.g., ATP synthesis) and electron transport systems [12], and (iii) induces photoinhibitory conditions $[25,26]$. In view of the above it was hypothesized that for survival under As stress, A. annua may (i) increase the accumulation of APX and DHAR to detoxify ROS, (ii) increase the electron transport to overcome the shortage of ATP and NADPH, and (iii) enhance phytochelatin synthase $(p c s)$ and $\mathrm{ABC}$ transporter like protein genes for detoxification.

Taking recourse to the above the present study was undertaken to have an insight into (i) the metabolic proteins involved in As tolerance and to ascertain how far the physiological attributes go hand in hand with proteomic data and (ii) establish protein network between primary and secondary metabolism pathways. The results of this study enabled us to associate physiologically significant candidate proteins with As stress tolerance mechanism in A. annua.

\section{Materials and Methods}

2.1. Hydroponic Dose Screening. Artemisia annua L (family: Asteraceae) plants were cultured hydroponically as described by Rai et al. [11]. Briefly, seeds of $A$. annua were collected from Central Institute of Medicinal and Aromatic Plants (CIMAP), Lucknow, India, and grown in botanical garden, Banaras Hindu University, Varanasi, India. Twenty one days after germination, seedlings of equal size (approximately $10 \mathrm{~cm}$ ) were washed with deionized water and acclimated in a hydroponic system in $10 \%$ Hoagland's nutrient solution [27]. The nutrient solution was aerated continuously using an aquarium pump and renewed twice a week. Seedlings were kept in a controlled room with a $14 \mathrm{~h}$ light period, $100 \mu \mathrm{mol} \mathrm{m}{ }^{-2} \mathrm{~s}^{-1}$ photosynthetic photon flux density (PPF), $28 / 26^{\circ} \mathrm{C}$ day/night temperature, and $60-70 \%$ relative humidity. After one week, the plants were transferred into $10 \%$ strength Hoagland's nutrient solution, spiked with different doses such as 50,100 , and $150 \mu \mathrm{M}$ of As. Arsenate was applied as $\mathrm{Na}_{2} \mathrm{HAsO}_{4} \cdot 7 \mathrm{H}_{2} \mathrm{O}$. Experiments were conducted in triplicate in 150-mL Erlenmeyer flasks containing $100 \mathrm{~mL}$ of nutrient solution. Each replicate contained 3 plants of equal height (approximately $10 \mathrm{~cm}$ ). Control seedlings were never treated with As. Three replicates, each including the two concentrations and the control, were placed separately in growth chamber and were harvested after 7 days of treatment. After $7 \mathrm{~d}$ of As exposure no visible toxicity symptoms were seen up to $100 \mu \mathrm{M}$. Moreover, lower concentrations of As stimulated root growth and the biomass the maximum being 21.3 and $44.4 \%$, respectively, at $100 \mu \mathrm{M}$ As over the control. However, toxicity symptoms appeared and the root length decreased by $(6 \%)$ at $150 \mu \mathrm{M}$. This clearly indicated that plants fail to tolerate As beyond $100 \mu \mathrm{M}$ (data not shown). Based on these data, the diagnostic concentrations for the proteome analysis were set at 100 and $150 \mu \mathrm{M}$. Moreover, these doses represent the likely range of arsenic in contaminated lands of eastern Uttar Pradesh (U.P), India [28].

2.2. Pot Culture Experiment. Based on the results of the hydroponic study another set of pot culture experiments were conducted in natural conditions (field) using soil treated with similar doses of As, 100 and $150 \mu \mathrm{M}$ As in the form of sodium arsenate. Experiments were done in triplicate. The soil used for the pot experiments was alluvial, collected from the premises of botanical garden, Banaras Hindu University, Varanasi, India. The soil was mixed with sand at the ratio 
of $3: 1(\mathrm{v} / \mathrm{v})$. As solution was uniformly mixed with airdried soil, kept for one month to stabilize and filled in $16 \mathrm{~kg}$ pots. The soil without As treatment was used as control. Four seedlings of twenty-one day-old healthy A. annua were transplanted into each experimental pot. Soil moisture was maintained at $50-60 \%$ of field water holding capacity by adding water during the experimental period. Plants were grown under natural daylight and ambient temperature for eight months, after which they were harvested for protein isolation as well as to investigate the effects of As on flowering time, inflorescence, and other morphological as well as physiological characters.

\subsection{Extraction and Estimation of Arsenic and Phosphate.} Total As was estimated in an atomic absorption spectrometry (Perkin-Elmer; A Analyst 600) fitted with a graphite furnace [29]. The As reference standard of $1000 \mathrm{mg} \mathrm{mL}^{-1}$ (AA03N5) was supplied by Accustandard, USA. Total phosphate was extracted from shoots of control and As treated seedlings according to the method of Fiske and Subbarow [30]. Absorbance was measured at $660 \mathrm{~nm}$ using $\mathrm{KH}_{2} \mathrm{PO}_{4}$ as a phosphate standard.

2.4. Measurements of Photosynthesis and Chlorophyll Fluorescence. Photosynthetic rates $\left(P_{s}\right)$, stomatal conductance $\left(g_{s}\right)$, intercellular $\mathrm{CO}_{2}\left(C_{i}\right)$, water use efficiency (WUE), and transpiration rates $(E)$ of test plants were determined using a LI-6400, (LICOR Inc., Neb., USA) portable gas exchange system on the uppermost fully expanded leaves from each individual during the period from 8:30 a.m. to 10:30 a.m. in six randomly selected plants of each treatment. During the experiments, system was calibrated with known $\mathrm{CO}_{2}$ concentration of $509 \mathrm{ppm}$ and PAR ranged between 1000 and $1200 \mu \mathrm{mol} \mathrm{m}^{-2} \mathrm{~s}^{-1}$; Chlorophyll fluorescence was determined with a portable plant efficiency analyzer (Model PEAMK2 9414, Hansatech Instrument Ltd., Norfolk, UK) on the same leaf where $\left(P_{s}\right)$ was measured. WUE was calculated as the ratio of $P_{s}$ and $E$. Leaf clips for dark adaptation were placed on the adaxial side for 15 min before measurement at excitation irradiance of $2000 \mu \mathrm{mol} \mathrm{m}{ }^{-2} \mathrm{~s}^{-1}$. Minimum fluorescence $\left(F_{o}\right)$ and maximum fluorescence $\left(F_{m}\right)$ were measured. Variable fluorescence was calculated as $\left(F_{v}=F_{m}-F_{o}\right)$ and the ratio of variable to maximum fluorescence as $\left(F_{v} / F_{m}\right)$.

2.5. Measurement of ATP, NADP, PSI, PSII, and Whole Chain Activity. ATP and NADPH contents as well as PSI and PSII activities were measured on the uppermost fully expanded leaves of each treatment and control (sampled in six). The ATP pool was measured by the method of Larsson and Olssonl [31]. ATP was quantified using Luminometer (LKB, 1250). The NADPH/NADH level of the cell extract in Tris$\mathrm{Cl}(\mathrm{pH} 8.0)$ was measured by recording the absorbance at $340 \mathrm{~nm}$ [32]. PSI- and PSII-mediated electron transport were measured using isolated thylakoids with an oxygen electrode (digital oxygen system model-10, Rank Brothers, UK). Thylakoid was isolated from leaves using a modified protocol of Mishra and Sabat [33]. Leaves were crushed in extraction buffer containing $300 \mathrm{mM}$ sucrose, $10 \mathrm{mM} \mathrm{NaCl}$,
$10 \mathrm{mM} \mathrm{CaCl}$, $5 \mathrm{mM} \mathrm{MgCl}, 10 \mathrm{mM}$ ascorbate, and $20 \mathrm{mM}$ Tricine-NaOH ( $\mathrm{pH}$ 7.5). The homogenate was filtered and centrifuged at $6000 \mathrm{~g}$ for $10 \mathrm{~min}$. The pellet represents the thylakoid fraction and was suspended in $1 \mathrm{~mL}$ of buffer containing $100 \mathrm{mM}$ sucrose, $10 \mathrm{mM} \mathrm{NaCl}, 10 \mathrm{mM} \mathrm{CaCl}, 5 \mathrm{mM}$ $\mathrm{MgCl}_{2}$, and $20 \mathrm{mM}$ Tricine- $\mathrm{NaOH}$ ( $\mathrm{pH}$ 7.5). The reaction mixture for assaying PSII activity consisted of $50 \mathrm{mM} \mathrm{HEPES}$ buffer ( $\mathrm{pH}$ 7.5) containing $400 \mathrm{mM}$ sucrose, $5 \mathrm{mM} \mathrm{MgCl}$, and $10 \mathrm{mM} \mathrm{NaCl}$ in a final volume of $1 \mathrm{~mL}$. The activity was measured as oxygen evolution with water as electron donor and $500 \mu \mathrm{M}$ phenyl $p$-benzoquinone (pBQ) as the electron acceptor [34]. The whole-chain $\left(\mathrm{H}_{2} \mathrm{O}-\mathrm{MV}\right)$ electron transport was measured polarographically as $\mathrm{O}_{2}$ uptake. The $1 \mathrm{~mL}$ reaction mixture contained $20 \mathrm{mM}$ HEPES (pH 7.5), $100 \mathrm{mM}$ sucrose, $10 \mathrm{mM} \mathrm{NaCl}, 2 \mathrm{mM} \mathrm{MgCl}, 0.5 \mathrm{mM} \mathrm{MV}$, and $1 \mathrm{mM}$ sodium azide. In the third type of assay, the electron transport through PSI was also measured polarographically as above except that reduced DCPIP was used as the electron donor. Assay conditions were identical to those of whole chain assay except that $5 \mu \mathrm{M}$ DCMU (3-3,4-dichlorophenyl-1,1dimethylurea), $1 \mathrm{mM}$ sodium ascorbate, and $100 \mu \mathrm{M}$ DCPIP were added to the above reaction mixture. A thylakoid aliquot containing $10 \mu \mathrm{g}$ chlorophyll was used in the measurements. The chlorophyll content was estimated according to Arnon [35]. All the photochemical assays were carried out at a saturating intensity of white light $\left(1000 \mu \mathrm{E} \mathrm{m}^{-2} \mathrm{~s}^{-1}\right)$ at $26 \pm$ $2^{\circ} \mathrm{C}$.

2.6. Determination of Artemisinin and Anthocyanin Contents. Artemisinin was extracted and quantified by the method of Zhao and Zeng [36]. Concentration of artemisinin was measured using calibration curve of artemisinin standard. Anthocyanins were extracted from $1 \mathrm{~g}$ of fresh leaves with $20 \mathrm{~mL}$ of mixture: n-propanol: $\mathrm{HCl}: \mathrm{H}_{2} \mathrm{O}(18: 1: 81, \mathrm{v} / \mathrm{v} / \mathrm{v})$ according to Lange et al. [37] and Bette and Kutschera [38] in modification. Samples were heated in a boiling water bath for $10 \mathrm{~min}$ and then incubated for $24 \mathrm{~h}$ in the dark at $4^{\circ} \mathrm{C}$. The extract was filtered and its absorbance was measured at 529 and $650 \mathrm{~nm}$. The red peak absorbance for degraded chlorophyll in the sample extracts occurs at $650 \mathrm{~nm}$ and has a tail that overlaps with the anthocyanin peak at $529 \mathrm{~nm}$. Therefore, the absorbance of anthocyanin was corrected for the effect of chlorophyll using this equation: $\mathrm{AA}=A_{529^{-}}$ $\left(0.288 A_{650}\right)$ where AA is corrected anthocyanin absorbance. Total anthocyanin content was then calculated using this corrected absorbance and a molar absorbance coefficient for anthocyanin at $529 \mathrm{~nm}$ of $30,000 \mathrm{~mol}^{-1} \mathrm{~cm}^{-1}$ The content of total anthocyanins was expressed as $\mu \mathrm{mol}$ per g FW [39].

2.7. Protein Extraction and 2-DE Separation. The experiments were conducted in triplicate. Three plants per treatment (both $100 \& 150 \mu \mathrm{M})$ and control were collected after 8 months of pot culture experiment. Two leaves per replicate (2nd pair and weighing 0.5 to $1.0 \mathrm{~g}$ fresh weight) were ground in liquid nitrogen to a fine powder. The powder was suspended completely in $10 \mathrm{~mL}$ of TCA extraction buffer $(10 \% \mathrm{w} / \mathrm{v}$ TCA in acetone with $0.5 \% \mathrm{w} / \mathrm{v} \beta$-mercaptoethanol) at $-20^{\circ} \mathrm{C}$ overnight. After centrifugation at $6000 \times \mathrm{g}$, for $30 \mathrm{~min}$ at $4^{\circ} \mathrm{C}$ 
the pellets were washed 3 to 4 times with $10 \mathrm{~mL}$ ice cold acetone (with $0.5 \% \mathrm{w} / \mathrm{v} \beta$-mercaptoethanol). The collected protein pellets were dried in air. The dried powder was resuspended completely in $2 \mathrm{~mL}$ lysis buffer containing $7 \mathrm{M}$ urea, $2 \mathrm{M}$ thiourea, $4 \%$ CHAPS, $40 \mathrm{mM}$ DTT, and $1.0 \%$ IPG buffer (4-7). Traces of bromophenol blue were added and the solution was centrifuged at $19000 \times \mathrm{g}$ for $10 \mathrm{~min}$. Protein contents were quantified according to Bradford using BSA (bovine serum albumin) as a standard $\left(2 \mathrm{mg} \mathrm{mL}^{-1}\right)$ [40]. Sample entry was made through in-gel rehydration. A total of $300 \mu \mathrm{L}$ of solubilization buffer containing $250 \mu \mathrm{g}$ protein sample was incubated with the dry IPG strips ( $\mathrm{pH}$ $4-7 ; 13 \mathrm{~cm}$; GE healthcare, USA) at $20^{\circ} \mathrm{C}$ for $16 \mathrm{~h}$. The first dimension separation was conducted at $20^{\circ} \mathrm{C}$ with an Ettan IPGphor system (GE Healthcare BIO-Science, USA). Focusing was performed in 7 steps: linear $30 \mathrm{~V}$ for $00: 30 \mathrm{~h}$, $150 \mathrm{~V}$ for $2: 00 \mathrm{~h}, 300 \mathrm{~V}$ for $00: 40 \mathrm{~h}, 500 \mathrm{~V}$ for $4 \mathrm{~h}$, gradient $1000 \mathrm{~V}$ for $1 \mathrm{~h}$, gradient $8000 \mathrm{~V}$ for $2 \mathrm{~h}$, and finally $8000 \mathrm{~V}$ for 13:00 h. Focused IPG strips were then equilibrated by first incubating them in an equilibration solution (6 M urea, $30 \% \mathrm{v} / \mathrm{v}$ glycerol, $2 \% \mathrm{w} / \mathrm{v}$ SDS, $50 \mathrm{mM}$ Tris- $\mathrm{HCl}, \mathrm{pH} 8.8$, and $1 \% \mathrm{w} / \mathrm{v}$ DTT and a trace amount of bromophenol blue) for $15 \mathrm{~min}$, followed by incubation in $2.5 \% \mathrm{w} / \mathrm{v}$ iodoacetamide in the same equilibration solution instead of $1 \%$ DTT for $15 \mathrm{~min}$. The strip was placed on the top of $12.5 \%$ SDS-PAGE $(13 \times 15 \mathrm{~cm})$ and sealed with $0.5 \%$ agarose. Electrophoresis was carried out at $10 \mathrm{~mA} /$ gel for $30 \mathrm{~min}$ then $25 \mathrm{~mA} /$ gel for $5 \mathrm{~h}$ using a Hoefer SE 600 apparatus (Amersham Biosciences, USA). The gels were stained with CBB R-250 as described by Pandey et al. [41]. Three replicates of CBB stained gels from three independent biological samples were used for analysis.

2.8. 2-DE Gel Data Analysis. Gels were scanned and protein spots were analyzed by using PDQuest software version 7.1 (Bio-Rad). After background subtraction and spot detection, spots were matched. Missing values imputation was done by K-Nearest Neighbor (KNN) algorithm [MATLAB]. After missing values imputation, total spot intensity per gel was used to normalize spot intensities ( $\%$ of individual spot intensity $/ \Sigma \%$ spot intensity of each gel) to compensate for variations between gel replicates. These data sets were also log-transformed to reduce the spot volume-spot deviation dependency. Only spots with statistically significant (Duncan Multiple Range Test, DMRT, $P<0.05)$ and reproducible changes were considered valid, and the protein spots with an abundance ratio of at least 1.5 -fold were selected as differentially expressed proteins.

2.9. In-Gel Digestion and Peptide Extraction. 46 differentially expressed protein pots from CBB stained gels were manually excised and in-gel digestion was performed as per the protocol of Bruker Daltonics adapted from Schevchenko et al. [42]. $100 \mathrm{~mL}$ of washing solution (1:1 ratio of acetonitrile and $100 \mathrm{mM}$ ammonium bicarbonate) was added to excised spots and incubated for $30 \mathrm{~min}$ for destaining. It was further incubated in absolute acetonitrile for $3 \mathrm{~min}$ and pellets were air-dried. Reduction of the protein spots was done using $10 \mathrm{mM}$ DTT dissolved in $100 \mathrm{mM} \mathrm{NH}_{4} \mathrm{CO}_{3}$ for $1 \mathrm{~h}$ at $50^{\circ} \mathrm{C}$. The samples were further alkylated using $55 \mathrm{mM}$ iodoacetamide in $100 \mathrm{mM} \mathrm{NH}_{4} \mathrm{CO}_{3}$ for $45 \mathrm{~min}$ in dark at room temperature. The gel pieces were dehydrated with $100 \%$ acetonitrile, air-dried, and then digestion was done by using sequence-grade modified trypsin (Promega gold) which was added $(25 \mu \mathrm{g} / \mathrm{mL})$ in a digestion buffer containing $25 \mathrm{mM}$ ammonium bicarbonate to the dehydrated gel pieces. Ingel digestion of protein was performed overnight at $37^{\circ} \mathrm{C}$, followed by three extractions of peptides with $50 \%(\mathrm{v} / \mathrm{v})$, acetonitrile $0.1 \%(\mathrm{v} / \mathrm{v})$, and trifluoroacetic acid (TFA). Combined supernatants were dried in a vacuum centrifuge (Thermo electron corporation, UVS400A) for 2-4 h. Dry pellets were resuspended in a small volume $(3-5 \mathrm{~mL})$ of $0.1 \%(\mathrm{v} / \mathrm{v}) \mathrm{TFA}$ in $50 \%(\mathrm{v} / \mathrm{v})$ acetonitrile and stored at $-20^{\circ} \mathrm{C}$ until analysis.

2.10. Mass Spectrometry Analysis and Database Searching. For MS analysis, one microliter of alpha cyanocinnamic acid (CCA) matrix $(10 \mathrm{mg} / \mathrm{mL}$ in $50 \%$ acetonitrile and $0.1 \%$ TFA) (Sigma Aldrich, St. Louis, Missouri, USA) was mixed with $1 \mu \mathrm{L}$ of digested protein samples. The mixture was spotted on MALDI target plate (MTP 384 ground steel, Bruker Daltonics, Germany) and allowed to form the crystals. The peptide spectra was acquired in an AUTOFLEX speed MALDI TOF/TOF instrument (Bruker Daltonics, Germany) having Nd: YAG smart Laser beam of $335 \mathrm{~nm}$ wavelength. External calibration was done with peptide calibration standard supplied by Bruker, with masses ranging from 1046 to $3147 \mathrm{Da}$. The obtained spectra were acquired using FlexControl version 3.3 software (Bruker Daltonics, Germany) in reflectron ion mode with an average of 2000 laser shots at the $\mathrm{m} / \mathrm{z}$ detection range between 700 and 4000 . The peak list was generated automatically and at least their most intense and discriminating peaks were subjected to further MS/MS fragmentation in LIFT mode.

Accelerating voltage:

Ion Source-1 $19 \mathrm{kV}$ and Reflectron (grid)-1 $21 \mathrm{kV}$
Ion Source-2 $16 \mathrm{kV}$ and Reflectron (grid)-
$29.65 \mathrm{kV}$.

The data were analyzed using Flex Analysis software version 3.3 (Bruker Daltonics, Germany) and searched in MASCOT web server (Matrix Science; http://www.matrixscience.com) using Biotools version 3.2 software (Bruker Daltonics, Germany). The protein databases employed were NCBInr (The National Center for Biotechnology Information nonredundant) and Swiss-Prot (date of access, 5. 11. 2012). A combined peptide mass fingerprinting (PMF) and tandem MS/MS were performed with the following MASCOT settings: taxonomy as Viridiplantae; peptide mass tolerance of \pm 100 ppm for peptide mass fingerprinting and $\pm 1.2 \mathrm{Da}$ for MS/MS, monoisotopic mass, alkylation of cysteine by carbamidomethylation as a fixed modification and oxidation of methionine as a variable modification. Proteins with threshold MASCOT score $>43(P<0.05)$ were considered as significant match. The peptide sequences with highest scores of each spot were validated by BLAST P analysis. Also, the borderline MASCOT hits that showed poor score and those annotated as unknown, predicted, or hypothetical proteins were further 
searched in BLAST P analysis against the NCBI nr database to query their homology.

2.11. RNA Isolation and DNase Treatment. Total RNA was isolated from the control and As treated leaf samples in TRIZOL reagent (GIBCO-BRL) using the instructions given in the manufacturer's protocol. Briefly, $100 \mathrm{mg}$ of leaf samples was ground in liquid nitrogen and mixed with TRIzol reagent. After centrifugation at $12,000 \mathrm{~g}$ for $15 \mathrm{~min}$ at $4^{\circ} \mathrm{C}$, the upper aqueous layer containing RNA was removed and placed in a new centrifuge tube. About $0.5 \mathrm{~mL}$ of isopropyl alcohol per $1 \mathrm{~mL}$ of TRIzol was used to precipitate RNA. This suspension was centrifuged at $12,000 \mathrm{~g}$ for $8 \mathrm{~min}$ at $4^{\circ} \mathrm{C}$ and the pellet washed with $75 \%$ ethanol and resuspended in $50 \mu \mathrm{L}$ DEPC treated water. Forty units of RNase free DNase was added to remove any contaminating DNA followed by heating at $70^{\circ} \mathrm{C}$ for $5 \mathrm{~min}$ to denature the DNase. The quality of RNA was checked on a $1.0 \%$ agarose gel and the concentration determined by measuring the absorbance at $260 \mathrm{~nm}$.

2.12. Primer Design and RT-PCR Analysis. The cDNAs of DXS, DXR, HMGR, GPPS, FPS, and CHS were synthesized using RT-PCR based on the A. annua nucleotide sequences published in database. The database employed was GenBank (GenBank accession numbers AF182286, AF182287, AF142473, and AF112881, AF112881, resp.). The sequences of the primers used for PCR amplifications are listed in Supplementary Table S2 in Supplementary Material available online at http://dx.doi.org/10.1155/2014/163962. Amplification was performed with initial denaturation at $94^{\circ} \mathrm{C}$ for $5 \mathrm{~min}$, followed by 30 cycles of $30 \mathrm{~s}$ at $94^{\circ} \mathrm{C}, 30 \mathrm{~s}$ at $54^{\circ} \mathrm{C}, 90 \mathrm{~s}$ at $72^{\circ} \mathrm{C}$, and a final extension at $72^{\circ} \mathrm{C}$ for $10 \mathrm{~min}$. Ribosomal protein S9 (RPS9) was used as an internal reference gene. The amplification of each gene was repeated at least twice. Since the genome of $A$. annua is largely unsequenced, to design the gene specific primers, such as of GAPDH and PAL, the highly conserved region was picked up through multiple sequence alignment of different dicot sequences available in database by using Primer 3 software and these primers were used to amplify genomic DNA from A. annua. Specificity of all the primers was confirmed by sequence analysis of RTPCR amplicons derived from A. annua.

2.13. Western Blot Analysis. SDS-PAGE was carried out as per the method of Mishra et al. [43]. $20 \mu \mathrm{g}$ protein was separated by SDS-PAGE and electroblotted onto PVDF membrane (Millipore Immobilon-P), using a dual Mini-electroblot system (Precision Instruments, Varanasi, India) as described [44]. The gel cassette was kept in transfer buffer $3.03 \mathrm{~g} / \mathrm{L}$ Tris base, $14.4 \mathrm{~g} / \mathrm{L}$ glycine, and $200 \mathrm{~mL} / \mathrm{L}$ methanol (99\% v/v pure) for $12 \mathrm{~h}$ or overnight at $15 \mathrm{~V}$ at $4^{\circ} \mathrm{C}$. Membrane was blocked for $4 \mathrm{~h}$ in TTBS (Tris buffer saline containing $0.1 \%$ Tween$20)$ and $5 \%(\mathrm{w} / \mathrm{v})$ nonfat dried milk. The primary antibody (anti-PCS antibody) was diluted as per the instructions of the donors. The membrane incubated overnight at $4^{\circ} \mathrm{C}$ in the diluted solution of the primary antibody was washed five times for $5 \mathrm{~min}$ each in TTBS. This was then incubated in a Goat anti-Rabbit IgG HRP (horseradish peroxidases) conjugated secondary antibody (Genei, India) for $4 \mathrm{~h}$. Following four consecutive $5 \mathrm{~min}$ wash in TTBS the membrane was developed with $\mathrm{DAB} / \mathrm{NiCl}_{2}$ visualization solution. The reaction was terminated by washing the PVDF membrane with deionized distilled water. The blots were dried between filter paper, which considerably reduced the background staining. Polyclonal antibodies used for the detection of PCS by immunoblotting were obtained as generous gift from Dr. Stephan Cuine (CEA Cadarache, France). The immunoblotswere photographed using a gel documentation system (Bio-Rad, USA) and their quantitative densitometric analysis was performed using the Quantity One Software (Bio-Rad, USA).

2.14. Statistical Analysis. The statistical significance of the data was analyzed using one-way ANOVA, followed by Duncan's new multiple range test (DMRT) using the statistical software package SPSS 12.0. The results were accepted as significant at $P<0.05$. All values shown in the figures and tables are means \pm SD. For statistical treatment and cluster analysis of protein abundance values, the web-based software NIA array analysis tool used was Sharov et al. [44] available at http://gsun.grc.nia.nih.gov/anova/index.html. This software tool selects statistically valid protein spots based on analysis of variance (ANOVA). The data (MS excel sheet with indication of biological replications) were statistically analyzed using the following settings: error model "max (average, actual)," 0.01 proportion of highest variance values to be removed before variance averaging, 10 degrees of freedom for the Bayesian error model, 0.05 FDR threshold, and zero permutations. Hierarchical clustering was performed to check the reproducibility of data set (based on 39 differentially expressed protein spots), and the results were represented in dendrograms using the Euclidean distance. PCA was done using the following settings: covariance matrix type, three principal components, 1-fold change threshold for clusters, and 0.6 correlation threshold for clusters. PCA results were represented as a biplot, with proteins with similarity in expression pattern located in the same area of the graph.

\section{Results}

3.1. Arsenic and Phosphate Concentrations. A. annua accumulated As in a concentration dependent manner in both root and shoots. Maximum As content was found to be $\left(191.01 \mu \mathrm{gg}^{-1} \mathrm{DW}\right)$ in $150 \mu \mathrm{M}$ As treatment as compared to the control $\left(6.08 \mu \mathrm{gg}^{-1} \mathrm{DW}\right)$. In contrast, phosphate concentration showed a dose dependent decrease with lowest value in the $150 \mu \mathrm{M}$ As treated plants as compared to the control (Supplementary Table S1).

3.2. Morphological Responses of A. annua to As Stress. Upon visual inspection, $A$. annua plants did not show any phytotoxicity symptoms at $100 \mu \mathrm{M}$ As concentration. The plants looked healthy and green with an increased biomass, affirming their tolerant nature (Figure 1, Table 1). In contrast, $150 \mu \mathrm{M}$ As treated plants showed visible toxicity symptoms 


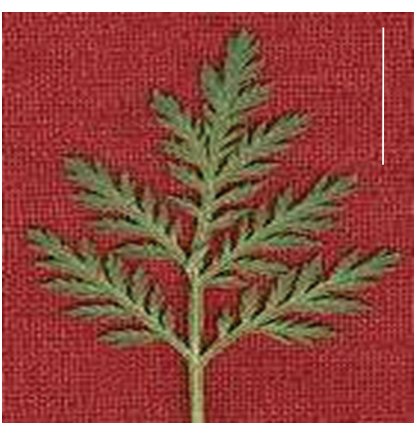

(a)

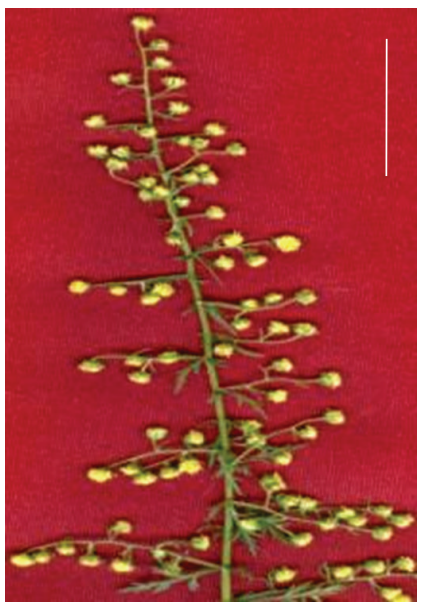

(d)

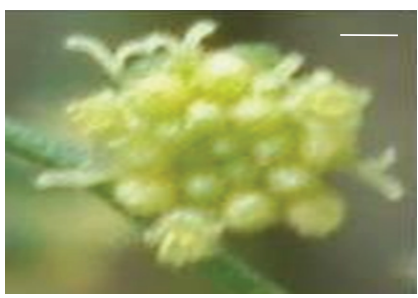

(g)

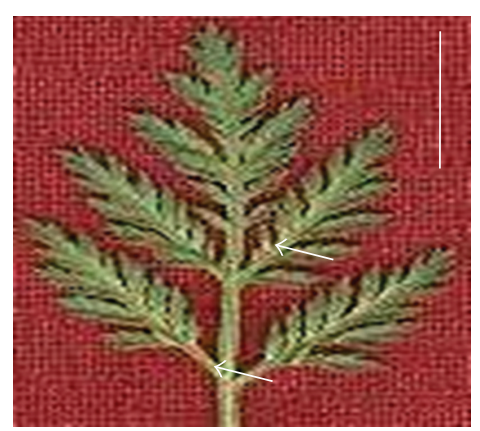

(b)

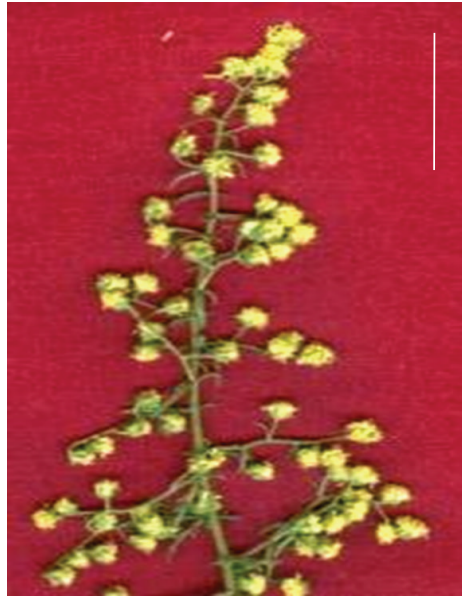

(e)

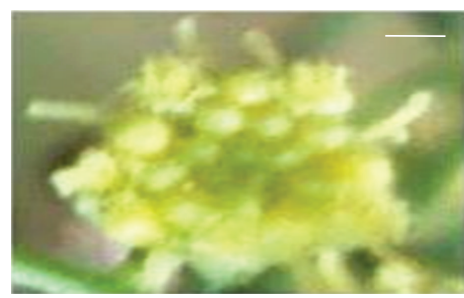

(h)

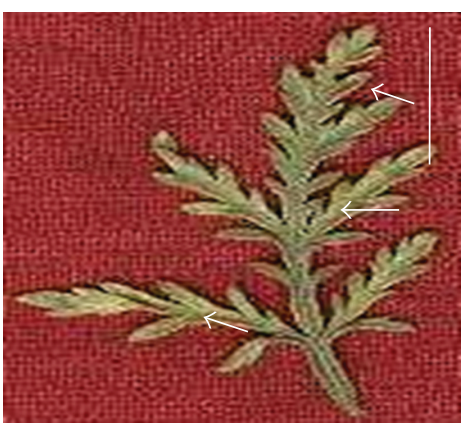

(c)

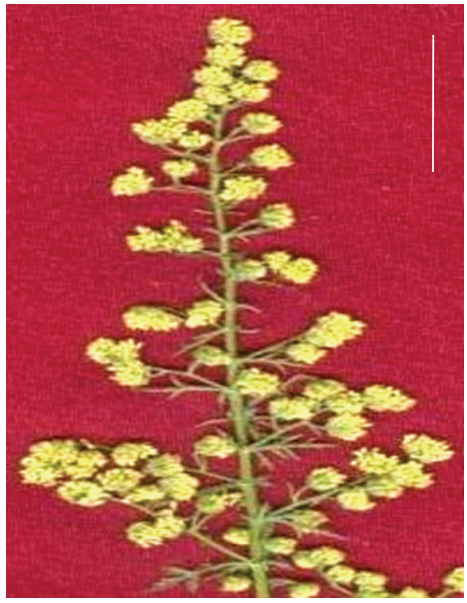

(f)

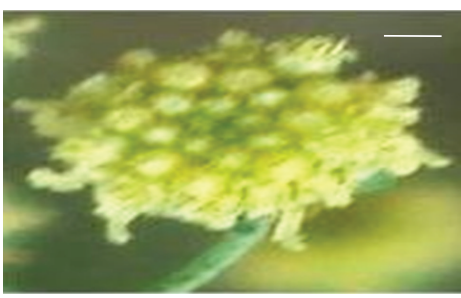

(i)

FIGURE 1: Morphological and physiological alterations in Artemisia annua seedlings; anthocyanin deposition in leaflets as indicated by white arrows; control (a), $100 \mu \mathrm{M}$ (b), $150 \mu \mathrm{M}$ As treatments. Number of inflorescence and inflorescence branches; control (d), $100 \mu \mathrm{M}$ (e), and $150 \mu \mathrm{M}$ As treatments (f). Florets size and number; control (g), $100 \mu \mathrm{M}(\mathrm{h})$ under $150 \mu \mathrm{M}$ As treatment (i). A B C bar indicates $4 \mathrm{~cm}, \mathrm{D}$ E F bar indicates $2.5 \mathrm{~cm}$, and G H I bar indicates $1 \mathrm{~mm}$.

such as wilting, whitish chlorosis in young leaves and yellowing and necrosis in old leaves (Figure 1(c)). The most emblematic symptoms observed under $150 \mu \mathrm{M}$ As treatments were intense red coloration of leaflets particularly at the apex (Figure 1(c)). The pigment analyses from leaves of comparable developmental stages revealed a 3.0-fold higher anthocyanin content in $150 \mu \mathrm{M}$ As treated plants compared to the control (Table 1). The data compiled in Table 1 depicted an inhibitory effect of As on plant height, number of inflorescence, and inflorescence branches being more pronounced at $150 \mu \mathrm{M}$ As concentrations. Interestingly, however, the number of florets, the size of capitula, the ratio of capitula/inflorescence, and the number of oil glands were found to be increased significantly under As treatments conceivably contributing to the higher artemisinin and essential oils production in As treated plants (Table 1, Figures 1(h) and 1(i)). Another remarkable observation made was the early onset of flowering in As treated plants. As treated plants flowered about 4-5 weeks before than control plants after sowing (Table 1).

3.3. Physiological Responses of A. annua to As Stress. Table 2 compiles data on the various physiological traits such as photosynthetic rate $\left(P_{s}\right)$, stomatal conductance $\left(g_{s}\right)$, transpiration rate $(E)$, intercellular $\mathrm{CO}_{2}$ concentration $\left(C_{i}\right)$, water use efficiency (WUE), and chlorophyll fluorescence emission patterns $\left(F_{v} / F_{m}\right)$ of control and As treated A. annua plants. While in the $100 \mu \mathrm{M}$ As treatments $P_{s}$ was found to be slightly 


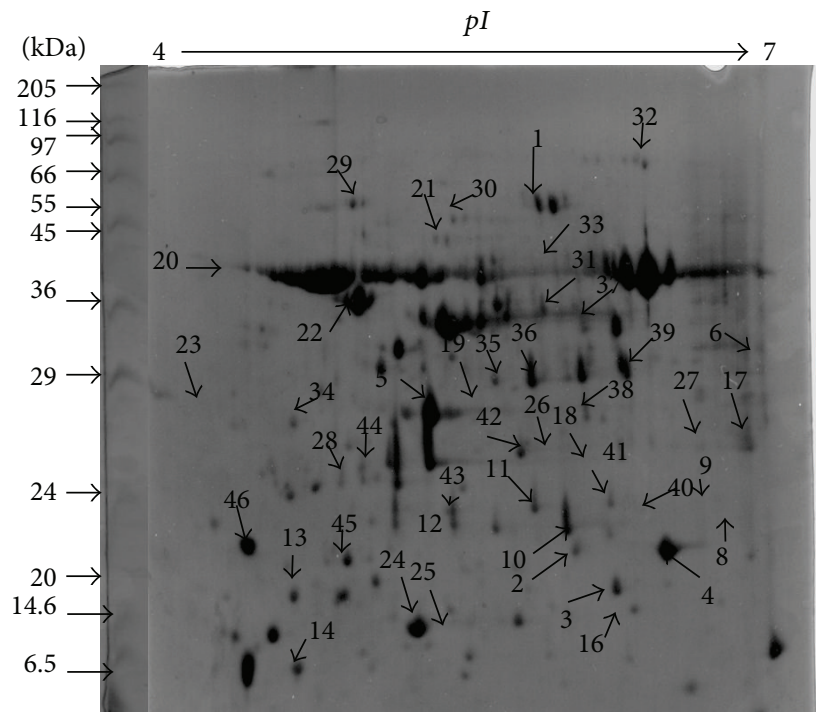

Control

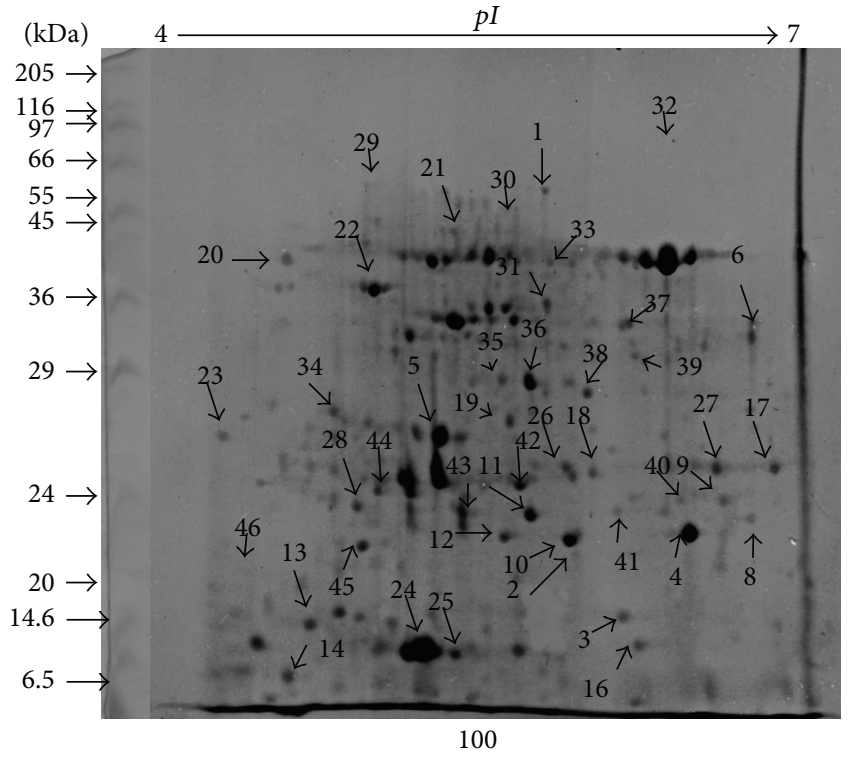

(b)

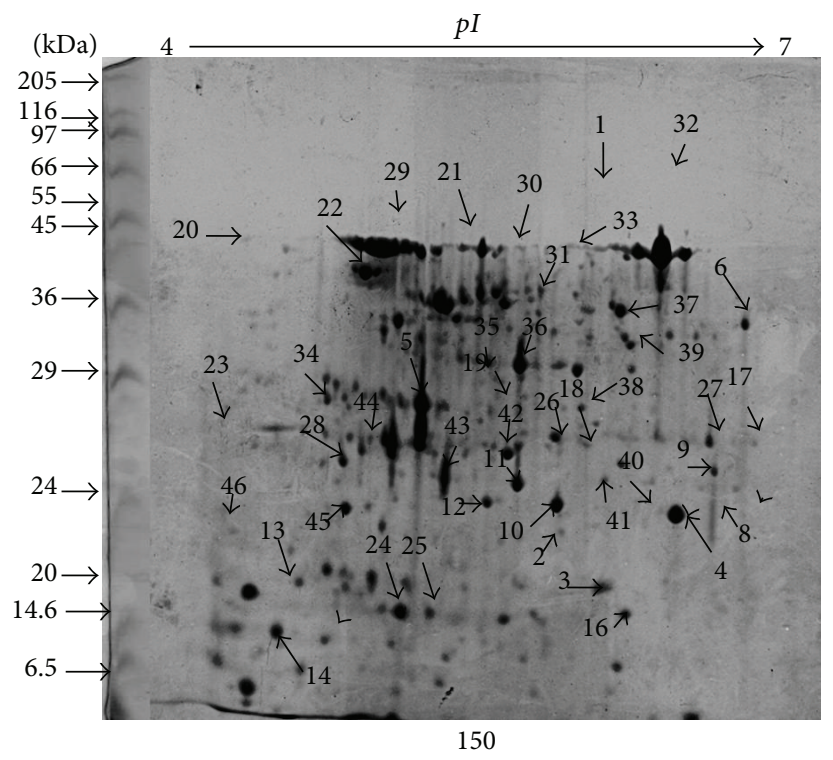

(c)

Figure 2: The 2-DE images of cytosolic protein extracts from Artemisia annua (a) control, (b) $100 \mu \mathrm{M}$, and (c) $150 \mu \mathrm{M}$ As. All gels were run in triplicate. Proteins were extracted and separated by $2-\mathrm{DE}$ and visualized by CBB staining. The protein ( $250 \mu \mathrm{g})$ was applied to pH $4-7 \mathrm{IPG}$ dry strips with $12.5 \%$ linear vertical SDS-PAGE as the second dimension. The arrows with numbers on 2-DE gel indicate the differentially expressed proteins, which were further identified by MALDI-MS/MS analysis. The molecular mass marker (Sigma) and $p I$ are indicated on the left side and above the gels, respectively.

depressed by (4.7\%) and was near the control, the $150 \mu \mathrm{M}$ As treatments resulted in a reduction of the leaf photosynthetic activity by $26 \%$ with respect to the control. With regard to $g_{s}$, the value of this parameter decreased by $18 \%$ and $23 \%$ in 100 and $150 \mu \mathrm{M}$ As treatments, respectively. However, in contrast, the intercellular $\mathrm{CO}_{2}$ concentration showed a little increase under $100 \mu \mathrm{MAs}$ treatments, although was equivalent to the control Transpiration rate demonstrated a negligible decrease under As treatments. An increase in the water use efficiency
(WUE) due to As stress was observed in both treatments, being $37 \%$ and $34 \%$ of the control in $100 \mu \mathrm{M}$ and $100 \mu \mathrm{M}$ As treatments, respectively. Considering photosynthetic electron transport chain activities, PSII demonstrated a minor decline of $11 \%$ and $34 \%$ in $100 \mu \mathrm{M}$ and $150 \mu \mathrm{M}$ As treatments, respectively, whereas PSI showed a significant increase of $70 \%$ in $100 \mu \mathrm{M}$ As treatments. In addition, the chlorophyll fluorescence parameters were monitored to determine the performance of photosystem 2 (PSII). The $F_{v} / F_{m}$ ratio is 
TABLE 1: Effect of As on various morphological and physiological parameters including, plant height, flowering time, number of inflorescences/plant, number of branches/inflorescence, number of capitula/inflorescence, capitula size, florets distance in whorl, number of florets/capitulum, number of oil glands, and artemisinin and anthocyanin contents in A. annua plants. Measurements were conducted under natural conditions when plants were 8-month old.

\begin{tabular}{|c|c|c|c|}
\hline Characters & Control & $100 \mu \mathrm{M}$ & $150 \mu \mathrm{M}$ \\
\hline Mature plant height (m) & $1.4 \pm 0.04^{\mathrm{a}}$ & $1.2 \pm 0.02^{\mathrm{a}}$ & $1.1 \pm 0.09^{\mathrm{a}}$ \\
\hline Time of first flower & 30-31 weeks & 28-29 weeks & 22-24 weeks \\
\hline Number of inflorescence/plant & $28 \pm 1.02^{\mathrm{a}}$ & $27 \pm 1.34^{\mathrm{ab}}$ & $24 \pm 0.98^{c}$ \\
\hline $\begin{array}{l}\text { Number of } \\
\text { branches/inflorescence }\end{array}$ & $23 \pm 1.1^{\mathrm{a}}$ & $21 \pm 1.1^{\mathrm{a}}$ & $18 \pm 1.4^{\mathrm{b}}$ \\
\hline Number of capitula/inflorescence & $20 \pm 1.02^{\mathrm{b}}$ & $32 \pm 0.98^{\mathrm{a}}$ & $33 \pm 1.04^{\mathrm{a}}$ \\
\hline Capitula size (mm) & $4.3 \pm 0.95^{\mathrm{c}}$ & $5.1 \pm 0.76^{\mathrm{b}}$ & $5.4 \pm 0.01^{\mathrm{a}}$ \\
\hline $\begin{array}{l}\text { Distance of florets in involucre } \\
\text { whorl (mm) }\end{array}$ & $1.1 \pm 0.004^{\mathrm{a}}$ & $1.0 \pm 0.01^{\mathrm{a}}$ & $0.8 \pm 0.003^{\mathrm{b}}$ \\
\hline Florets/capitulum & Disc $=35$ & Disc $=45$ & Ray $=17$ \\
\hline $\begin{array}{l}\text { Artemisinin content } \\
(\mathrm{mg} / 100 \mathrm{~g} \mathrm{DW})\end{array}$ & $0.39 \pm 0.02^{\mathrm{a}}$ & $0.46 \pm 1.02^{\mathrm{a}}$ & $0.52 \pm 0.02^{\mathrm{a}}$ \\
\hline Number of oil glands/florets & $5 \pm 0.05^{\mathrm{c}}$ & $7 \pm 0.09^{\mathrm{b}}$ & $9.9 \pm 0.01^{\mathrm{a}}$ \\
\hline $\begin{array}{l}\text { Anthocyanin content }\left(\mu \mathrm{mol} \mathrm{g}^{-1}\right. \\
\text { FW) }\end{array}$ & $0.06 \pm 0.01^{\mathrm{a}}$ & $0.07 \pm 0.06^{\mathrm{a}}$ & $0.12 \pm 0.09^{\mathrm{a}}$ \\
\hline Biomass (DW g plant ${ }^{-1}$ ) & $241 \pm 4.5^{\mathrm{b}}$ & $267.0 \pm 5.2^{\mathrm{a}}$ & $221 \pm 5.0^{c}$ \\
\hline
\end{tabular}

All values are mean $\pm \mathrm{SD}(n=3)$. Different letters show significantly different values $(P<0.05$, DMRT).

TABLE 2: Photosynthetic rate $\left(P_{s}\right)$, stomatal conductance $\left(g_{s}\right)$, intercellular $\mathrm{CO}_{2}\left(C_{i}\right)$, transpiration rate $(E)$, water use efficiency $\left(\right.$ WUE), $F_{v} / F_{m}$ (the maximal photochemical efficiency), photosystem I activity (PS-I), photosystem II activity (PS-II), whole chain electron transport chain, ATP and NADPH contents of control, and As treated A. annua plants. Measurements were conducted when plants were 8-month old.

\begin{tabular}{|c|c|c|c|}
\hline Physiological parameters & Control & $100 \mu \mathrm{M}$ & $150 \mu \mathrm{M}$ \\
\hline$P_{s}\left(\mu \mathrm{mol} \mathrm{CO}_{2} \mathrm{~m}^{-2} \mathrm{~s}^{-1}\right)$ & $31.7 \pm 0.43^{\mathrm{a}}$ & $30.0 \pm 0.78^{\mathrm{b}}$ & $23.5 \pm 0.99^{c}$ \\
\hline$g_{s}\left(\mathrm{~mol} \mathrm{H}_{2} \mathrm{O} \mathrm{m}^{-2} \mathrm{~s}^{-1}\right)$ & $0.44 \pm 0.04^{\mathrm{a}}$ & $0.36 \pm 0.07^{\mathrm{a}}$ & $0.34 \pm 0.08^{\mathrm{a}}$ \\
\hline$C_{i}(\mathrm{ppm})$ & $201.0 \pm 8.9^{\mathrm{a}}$ & $189.0 \pm 9.7^{\mathrm{a}}$ & $212.0 \pm 5.7^{\mathrm{a}}$ \\
\hline$E\left(\mathrm{mmol} \mathrm{H}_{2} \mathrm{O} \mathrm{m}^{-2} \mathrm{~s}^{-1}\right)$ & $6.1 \pm 0.45^{\mathrm{a}}$ & $6.08 \pm 0.67^{\mathrm{a}}$ & $6.02 \pm 0.54^{\mathrm{a}}$ \\
\hline WUE $\left(\mu \mathrm{mol} \mathrm{mol}{ }^{-1}\right)$ & $3.2 \pm 0.02^{\mathrm{b}}$ & $5.1 \pm 0.82^{\mathrm{a}}$ & $4.9 \pm 1.1^{\mathrm{a}}$ \\
\hline$F_{v} / F_{m}$ & $0.82 \pm 0.01^{\mathrm{a}}$ & $0.79 \pm 0.02^{\mathrm{a}}$ & $0.72 \pm 0.04^{\mathrm{b}}$ \\
\hline PS-I activity $\left(\mu \mathrm{mol} \mathrm{O}{ }_{2}\right.$ consumed $\left.\mathrm{mg}^{-1} \mathrm{Chl} \mathrm{h}^{-1}\right)$ & $250 \pm 9.01^{c}$ & $375 \pm 11.0^{\mathrm{a}}$ & $279 \pm 10.0^{\mathrm{b}}$ \\
\hline PS-II activity $\left(\mu \mathrm{mol} \mathrm{O}{ }_{2}\right.$ evolved $\left.\mathrm{mg}^{-1} \mathrm{Chl} \mathrm{h}^{-1}\right)$ & $225 \pm 11.0^{\mathrm{a}}$ & $199 \pm 12.0^{\mathrm{b}}$ & $154 \pm 12.0^{c}$ \\
\hline Whole chain $\left(\mu \mathrm{mol} \mathrm{O} \mathrm{O}_{2}\right.$ evolved $\left.\mathrm{mg}^{-1} \mathrm{Chl} \mathrm{h}^{-1}\right)$ & $148 \pm 12^{\mathrm{a}}$ & $149 \pm 22.3^{\mathrm{a}}$ & $109 \pm 11^{\mathrm{b}}$ \\
\hline $\operatorname{ATP}\left(\mu \mathrm{mol} \mathrm{g}^{-1} \mathrm{FW}\right)$ & $0.37 \pm 0.07^{\mathrm{a}}$ & $0.40 \pm 0.12^{\mathrm{a}}$ & $0.29 \pm 0.07^{\mathrm{a}}$ \\
\hline NADPH (nmol g $\left.{ }^{-1} \mathrm{FW}\right)$ & $5.17 \pm 0.61^{b}$ & $7.12 \pm 0.82^{\mathrm{a}}$ & $3.91 \pm 0.71^{\mathrm{b}}$ \\
\hline
\end{tabular}

All values are mean $\pm \mathrm{SD}(n=6)$. Different letters show significantly different values $(P<0.05$, DMRT).

correlated with the efficiency of leaf photosynthesis and a decline in this ratio is a good indicator of photoinhibitory damage under stress [45]. The $F_{v} / F_{m}$ ratios in the $100 \mu \mathrm{M}$ As treatments were slightly below 0.83 , which is the theoretical optimum [46]. In contrast it dropped down to 0.72 in the plants exposed to $150 \mu \mathrm{M}$ of As, indicating some damage in the PSII [47].

3.4. Biochemical Responses of A. annua to As Stress. Biochemical parameters including anthocyanin, artemisinin, ATP, and NADPH contents were measured from 8-month-old plants (Tables 1 and 2). Anthocyanin content was increased by $175 \%$ and $275 \%$ in 100 and $150 \mu \mathrm{M}$ As treatment, respectively. In tune with the above, the concentration of artemisinin was increased by 53.1 and $75 \%$ in 100 and $150 \mu \mathrm{M}$ As treatments, respectively, over the control (Table 1). While in $150 \mu \mathrm{M}$ As treatments, both NADPH and ATP contents decreased by $24 \%$ and $29 \%$, NADPH registered an increase of $29 \%$ in $100 \mu \mathrm{M}$ As treatments, but insignificant increase in ATP content was observed (Table 2).

3.5. 2-DE Analysis of As-Responsive Leaf Proteins in A. annua. Figure 2 presents a comparative account of the CBB stained gels of untreated control and 100 and $150 \mu \mathrm{M}$ As treated $A$. annua seedlings after 8 months of treatment. Quantitative image analysis using PD Quest Version 7.1 software (Bio-Rad) from three biologically independent replicate experiments revealed a total of $391 \pm 35,412 \pm 41$, and $447 \pm 27$ spots 


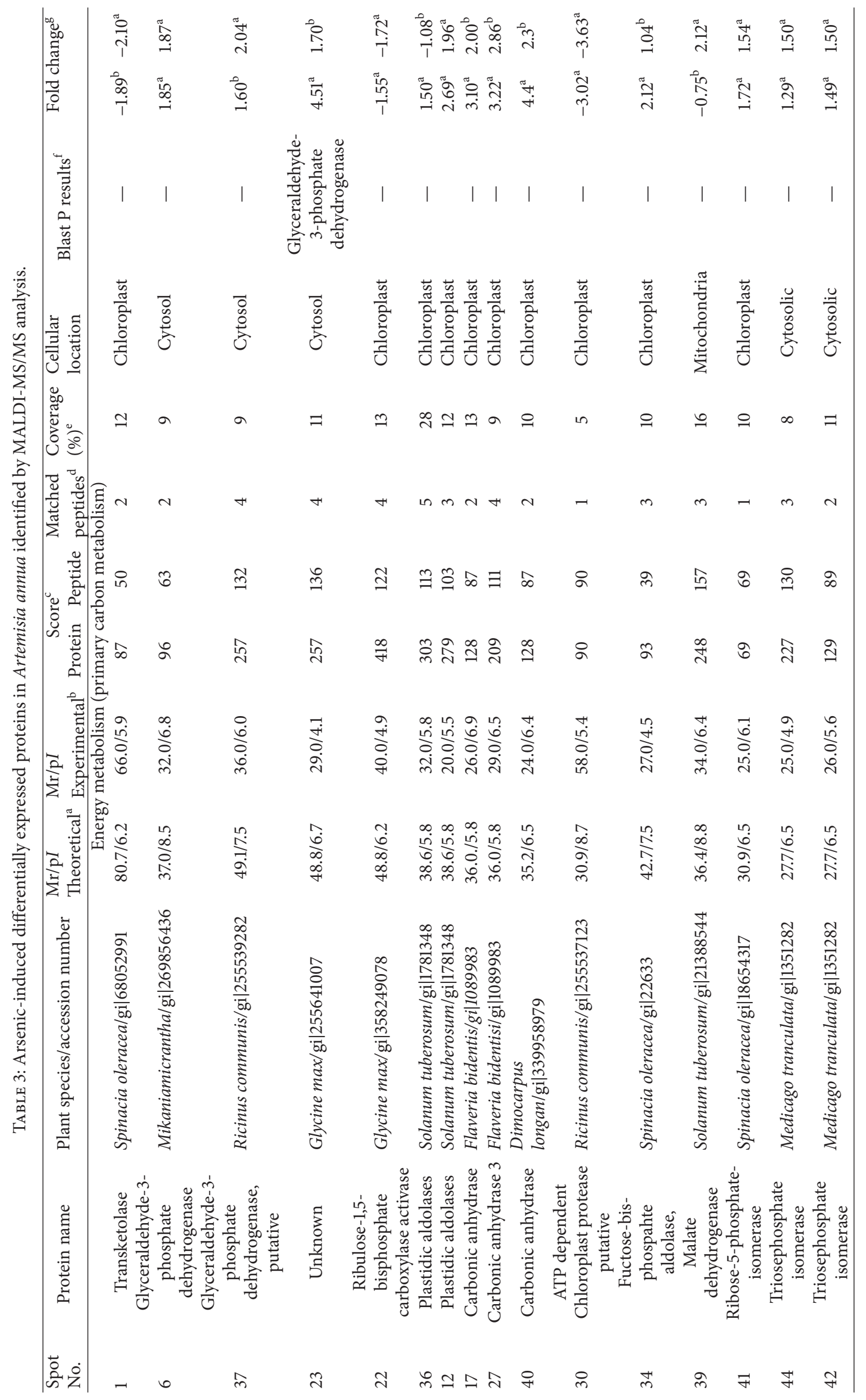




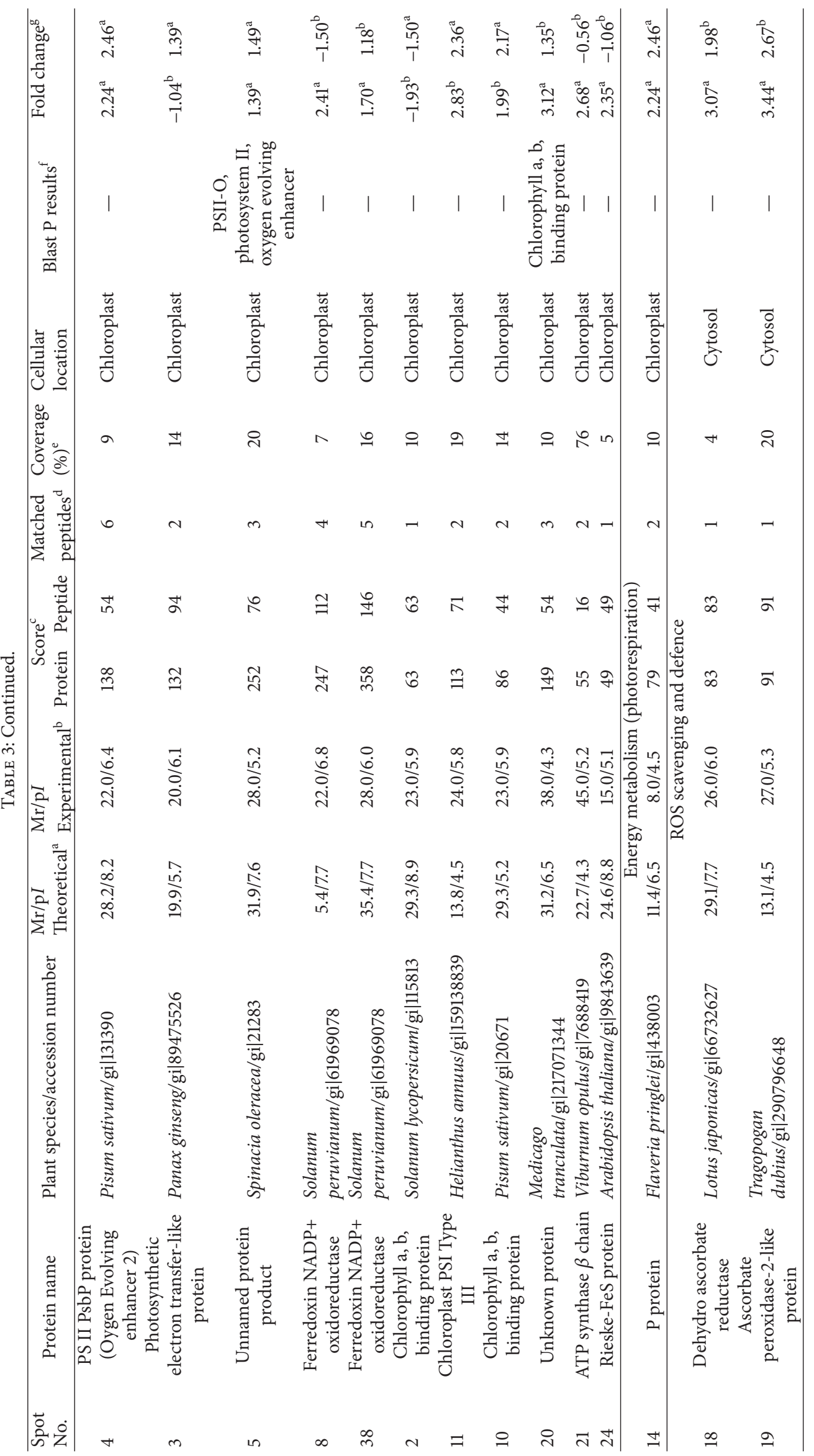




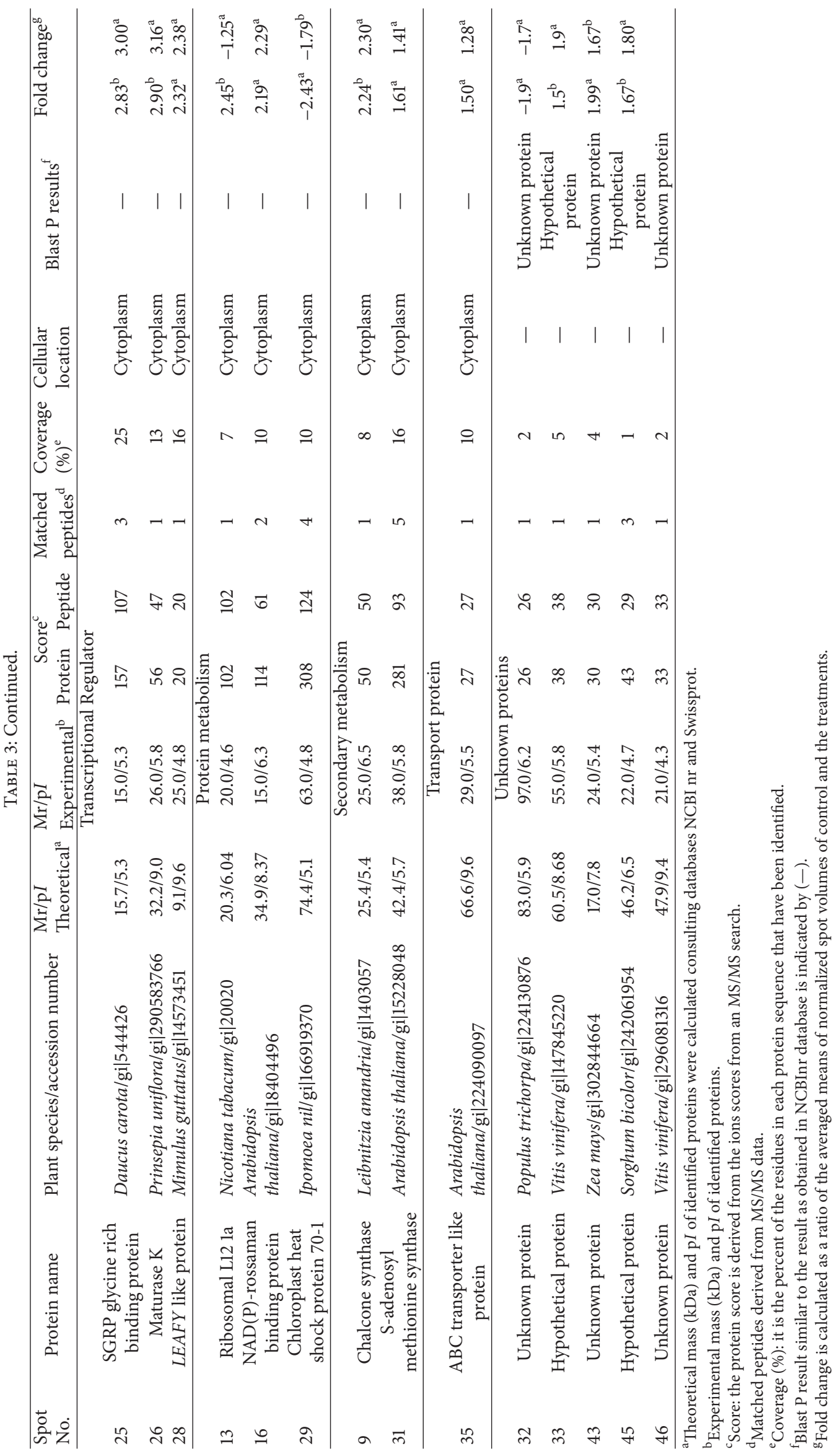


$100 \mu \mathrm{M}$ As versus control $\quad 150 \mu \mathrm{M}$ As versus control

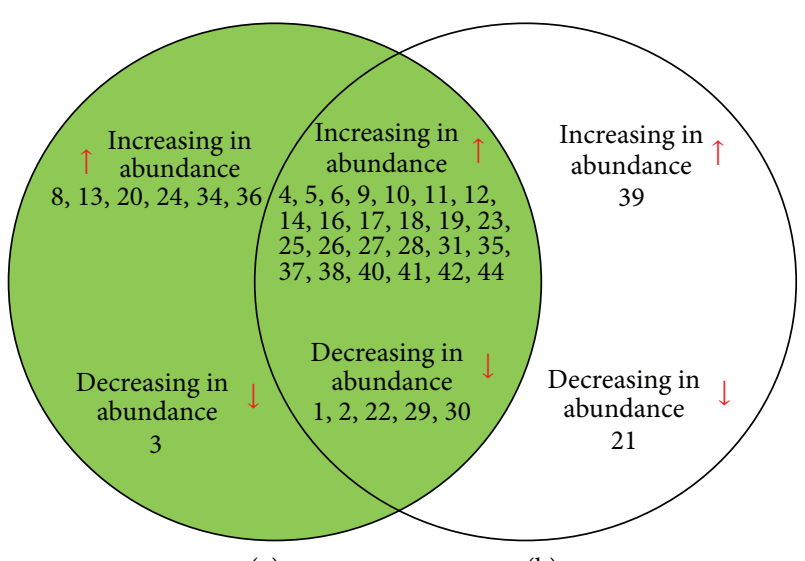

(a)

(b)

FIGURE 3: Venn diagram representation of differentially expressed protein spots of Artemisia annua affected under different As treatments. (a) and (b) represent 100 and $150 \mu \mathrm{M}$ As treatments versus control, respectively. Increase and decrease in abundance of protein abundance are indicated by the upward and downward arrows, respectively. Protein spots in the overlap region were common in both 100 and $150 \mu \mathrm{M}$ As treatments $(\mathrm{a} \cap \mathrm{b})$.

in the control, $100 \mu \mathrm{M}$ and $150 \mu \mathrm{M}$ As treatments in the range of $\mathrm{pH} 4-7$, and relative molecular masses $14-90 \mathrm{kDa}$. Supplementary Table S3 contains the description of the 2-DE proteomic experiment.

Fifty-one protein spots consistently changed their abundance (vol. \%) by $\geq 1.5$-fold in at least one of the As treatments. However, a spot displaying control versus treatment ratio of at least 1.5-fold and consistently present or absent in all three replicates was considered valid. Fold change was calculated as a ratio of the averaged means of normalized spot volumes of control and the treatments. Essentially arbitrarily threshold values ranging from 1.3 to 2.0 fold have been used in earlier proteomic studies $[48,49]$. Nevertheless, a 1.5 threshold value was selected in order to focus on the most responsive proteins and for consistency with previous proteomic and microarray experiments $[18,41,50]$. While most spots showed quantitative changes, few protein spots demonstrated qualitative changes. For example, spots 29, 30, and 32 were absent in As treated gels at one or more time points, whereas spots 9, 14, 39, and 40 were absent in the control gels (Supplementary Table S3). Raw data was processed in three steps, missing value estimation, normalization, and transformation. Analysis of variance before and after data transformation is given as Supplementary Table S4.

3.6. MALDI-TOF/TOF Analysis, Functional Classification, and Identification of As-Responsive Proteins. Forty-six differentially expressed protein spots (based on $P \leq 0.05$ ) with reproducible alterations were subjected to MALDITOF/TOF analysis (Supplementary Table S5). Figure 3 shows the Venn diagram of the differentially expressed proteins at different concentrations of As. From 46 spots excised, 37 were successfully identified; two were not hit (spots 7 and
15) whereas 7 proteins were annotated either as unknown, putative, or hypothetical proteins (Table 3, Supplementary Figure S1). To gain functional information about these proteins, BLASTP (http://www.ncbi.nlm.nih.gov/BLAST) was used to investigate their homologies with other proteins in the database. Of the seven proteins, three were successfully BLAST identified (spots 5, 20, and 23); however, spots 32, 33, 43,45 , and 46 showed a poor BLAST score. Since the genome of $A$. annua is still unsequenced therefore the MS/MS results (the peptide sequences with highest scores) of each spot were also validated by BLAST P analysis which revealed similarity thereby validating the MS/MS results. These proteins were sorted into 7 functional groups including energy metabolism, ROS scavenging and defense, secondary metabolism, transcriptional regulator, protein metabolism, transport, and unknown/unidentified proteins according to the ontological classification of Bevan et al. [51] (Supplementary Figure S2). BLAST search results are given as Supplementary Table S6.

\subsection{Expression Profiles of Proteins Associated in Different} Metabolic Pathways. Expression pattern of selected proteins of C, control, and 100, $150 \mu \mathrm{M}$ As treatmentsis depicted in Supplementary Figure S3. Few proteins were represented by more than one spot with slightly different $\mathrm{Mr}$ and $\mathrm{pI}$ values, although they were excised from the same gel. For example, Chl a/b type I was identified in four spots $(2,10$, 11 , and 20), NADP-ferredoxin oxidoreductase was identified twice ( 8 and 38), carbonic anhydrase was identified in three spots (17, 27, and 40), triose-phosphate-isomerase (spots 42 and 44), and glyceraldehyde-3-phosphate (spots 6, 23, and 37). Most of the protein matches and theoretical and experimental pI and Mr were in good agreement, supporting confidence in the identifications; however, some of the identified proteins showed discrepancy with their $\mathrm{Mr}$ and pI. These kinds of phenomena are commonly observed in 2-D gels for several reasons including protein migration, different isoforms derived from different genes, proteolytic cleavage, posttranslational modification variants of the same gene product, or artificial modification of proteins, such as carbamylation during protein extraction [52]. According to the expression pattern, the identified proteins are categorized as proteins showing increased or decreased abundance under 100 or $150 \mu \mathrm{M}$ As treatments. More than any functional group, energy metabolism proteins (60\%) were differentially expressed in $100 \mu \mathrm{M}$ As treatment and were divided into four functional subgroups: (1) chlorophyll a, b-binding proteins, (2) oxygen-evolving complex proteins of PSII, (3) proteins participating in the Calvin cycle, and (4) proteins involved in photosynthetic electron transport chain. The first subgroup harbored four protein species of chlorophyll a/b binding proteins (CP26 in PS II) displaying a mixed pattern of expression. While two isoforms of chlorophyll $\mathrm{a} / \mathrm{b}$ binding protein (spot 10 and spot 20), an unknown protein that was BLAST identified as chlorophyll a/b binding protein, were found in higher amounts in either 100 or $150 \mu \mathrm{M}$ As treatments, spot (2) was decreased in relative abundance in response to As stress. Another protein (spot 11) identified as chloroplast PS I type III chlorophyll $\mathrm{a} / \mathrm{b}$ binding protein 
was increased in relative abundance in $100 \mu \mathrm{M}$ As treatment. The second subgroup consists of oxygen-evolving complex protein (OECP2) where one intact protein (spot 4) was increased in relative abundance (2.3-fold in $100 \mu \mathrm{M}$ and 2.2fold in $150 \mu \mathrm{M}$ ), whereas one degraded unnamed protein product (spot 5) BLAST identified as oxygen-evolving complex protein (OEC1) was decreased in amounts (1.3-fold and 1.2-fold in 100 and $150 \mu \mathrm{M}$ As, resp.). The third subgroup consisted of 15 proteins. Most of the enzymes involved in different metabolic pathways such as plastidic aldolases (ALD, spot 12, 2.69-fold, and spot 36, 1.5-fold), fructose bisphosphatase aldolase class I (FBA, spot 36, 1.5-fold), glyceraldehyde 3-phosphate dehydrogenase (GAPDH, spot 6, 1.8 fold, spot 23, 3.1 fold, and spot 37, 1.6 fold), Ribose-5phosphate,3-epimerase (spot 41, 1.7 fold), triose-phosphateisomerase (spot 42, 1.6 fold and spot 44, 1.9-fold), and carbonic anhydrase (CA, spot 17, 3.1 fold, spot 27, 3.22 fold, and spot 40, 1.64-fold) were increased in relative abundance in $100 \mu \mathrm{M}$ As treatment except for transketolase (TK; spot 1) and RuBisCO activase (spot 22). Consistent with changes in Calvin cycle, three other important proteins involved in electron transport chain (fourth subgroup) such as, ATP synthase $\alpha$ subunit (spot 21,2.7-fold), rieske protein (FeS, spot 24, 2.4-fold), and ferredoxin-NADP reductase (FNR, spots 8 and 38, 2.4- and 1.7-fold) were significantly enhanced only under $100 \mu \mathrm{M}$ As treatments. A marked increase in $\mathrm{P}$ protein subunit of glycine decarboxylase (spot 14, 2.0fold in $100 \mu \mathrm{M}$ and 2.5 -fold in $150 \mu \mathrm{M}$ ) was found in Asstressed plants, this being more significant in case of $150 \mu \mathrm{M}$ As treatment. Cytoplasmic malate dehydrogenase $(\mathrm{MDH}$, spot 39) depicted a significant upregulation (2.12-fold) under $150 \mu \mathrm{M}$ As but no change under $100 \mu \mathrm{M}$ As treatment. Two upregulated antioxidant proteins identified in this study, dehydroascorbate peroxidase (DHAR, spot 18) and ascorbate peroxidase (APX, spot 19), revealed significant accumulation of 3.4- and 3.1-fold in $100 \mu \mathrm{M}$ As treatments. Three proteins of the transcriptional regulator category, namely, glycine rich RNA binding protein (SGRP, spot 25), maturase $\mathrm{K}$ (spot26), and $L E A F Y$ like protein (spot 28), displayed similar abundance patterns in 100 and $150 \mu \mathrm{M}$ As treatments, with a slightly higher amount in $150 \mu \mathrm{M}$ As treatments. Four protein spots belonged to protein metabolism category. Of the four proteins, the rossmann $\mathrm{NAD}(\mathrm{P})$ fold (spot16) was found to be increased in both 100 and $150 \mu \mathrm{M}$ As treatments, whereas ribosomal L 12 la (spot 13) revealed a 2.5-fold increase in 100 $\mu \mathrm{M}$ As treatments and decrease in abundance in $150 \mu \mathrm{M}$ As treatments. In contrast to the above, Hsp 70 (spot 29) and chloroplast protease (spot 30 ) revealed decrease in relative abundance under 100 and $150 \mu \mathrm{M}$ As treatments. Besides this, two proteins were identified belonging to secondary metabolism category. The spot number 31 was identified as S-adenosyl methionine synthase (SAMS), a signaling protein involved in biosynthesis of homocysteine and ethylene, and revealed a 1.5 -fold induction under $100 \mu \mathrm{M}$ As treatment. The other protein, chalcone synthase (spot 9), revealed a 2.2- and 2.3-fold increase in the amount of this protein under 100 and $150 \mu \mathrm{M}$ As treatments, respectively. Spot 35 was identified as a multidrug resistance-associated protein (MRP), a subclass of ATP-binding cassette $(\mathrm{ABC})$ transporters depicted a 1.5-fold upregulation under $100 \mu \mathrm{M}$ As treatment. There were five protein spots that did not find match to any of the characterized proteins in the database and hence were named as UK (unknown).

3.8. Multivariate Statistical Analysis of Protein Abundance. Principal component analysis (PCA) was done to obtain a more accurate grouping of the samples and to determine the most discriminant spots. In order to check out the reproducibility in the biological replicates, a hierarchical clustering was performed. Two main clusters were obtained in the dendrogram, namely, cluster 5 (control) and cluster 4 (100 and $150 \mu \mathrm{M}$ As treatments) (Figure 4(a)). This clustering indicated that 100 and $150 \mu \mathrm{M}$ As treatments had a somewhat similar protein abundance profiles but different from that of control. Moreover, the hierarchical clustering of biological repetitions confirmed that the data were reproducible for the experiments. PCA analysis indicated a distinct separation of 100 and $150 \mu \mathrm{M}$ As treatments (Figure 4(b)). Photosynthetic proteins were found in the categories of proteins correlated with PC1 (positive and negative direction) and PC3 (positive direction). Carbon metabolism proteins were found in the categories of proteins correlated with $\mathrm{PCl}$ (negative direction), PC2 (positive and negative direction), and PC3 (positive direction). Proteins belonging to transcription as well as protein metabolism category were found in PC1 (positive and negative direction) and PC3 (positive direction). Defense and stress-related proteins were found in $\mathrm{PCl}$ (negative direction). Transport proteins were found in PC3 (positive direction). A high proportion of photosynthetic, carbon metabolism and defense proteins were more abundant in $100 \mu \mathrm{M}$ As treatments with respect to the $150 \mu \mathrm{M}$ As treatments. The quantity of protein abundance change within a specific PC was calculated by the slope of regression of log-transformed protein abundance versus the corresponding eigenvector multiplied by the range of values within the eigenvector (Figure 4(c)).

3.9. RT-PCR Analysis of Isoprenoid/Artemisinin Biosynthetic Pathway Genes. The expression profile of eight genes encoding enzymes of isoprenoid (MEP) and artemisinin biosynthetic pathways were monitored in the control and As treated plants (Figure 5). While all the six genes were upregulated in response to $100 \mu \mathrm{M}$ As treatment, a significant overexpression of 4.4- and 1.2-fold was observed for 1-deoxyxylulose5-phosphate synthase (DXS) and 1-deoxy-D-xylulose 5phosphate reductoisomerase (DXR), respectively. A similar pattern of gene expression was observed under $150 \mu \mathrm{M}$ As treatment. GAPDH also depicted an induction of 1.0- and 1.1-fold under 100 and $150 \mu \mathrm{M}$ As treatments, respectively. In contrast, geranyl pyrophosphate synthase (GPPS) and 3hydroxy-3-methyl-glutaryl-CoA reductase (HMGR) showed minor down regulation in response to both As treatments (Figure 5).

\section{Discussion}

An integrated morphological, physiological, and proteomic approach has been used for the first time to investigate 
1 Control

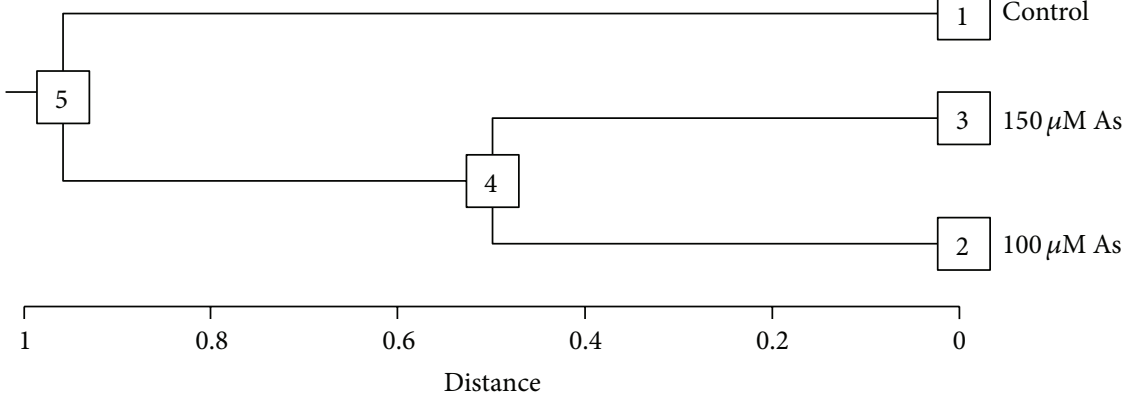

(a)
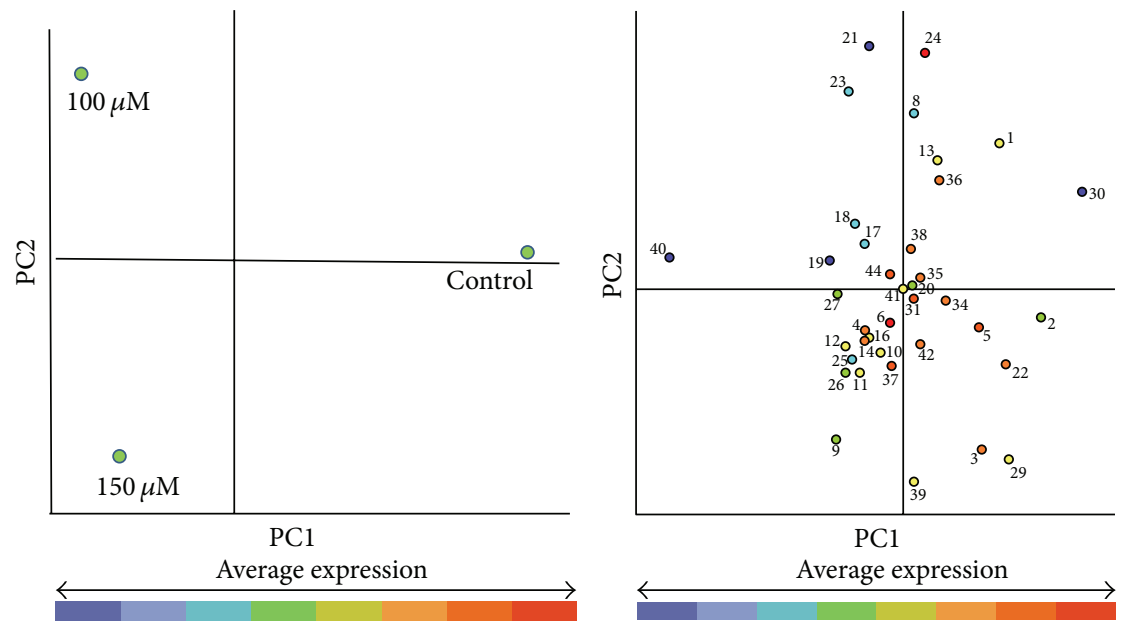

(b)

Principal components
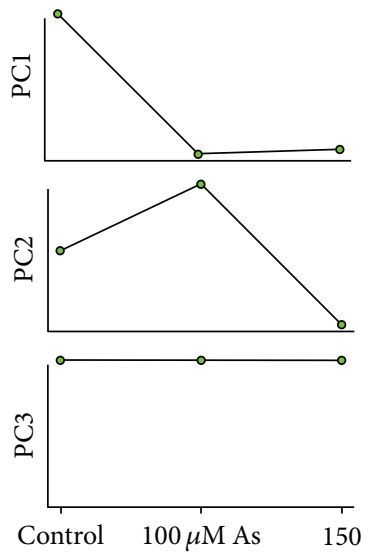

Centered intensity

- Average
Positive direction
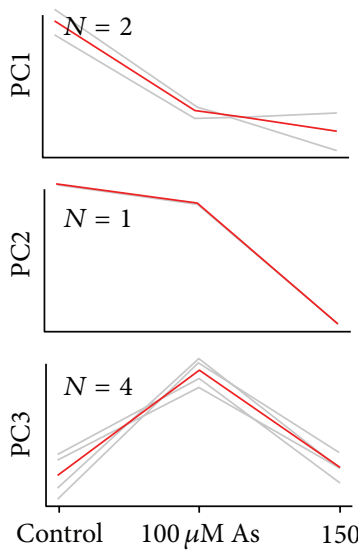

Centered intensity Average
Negative direction
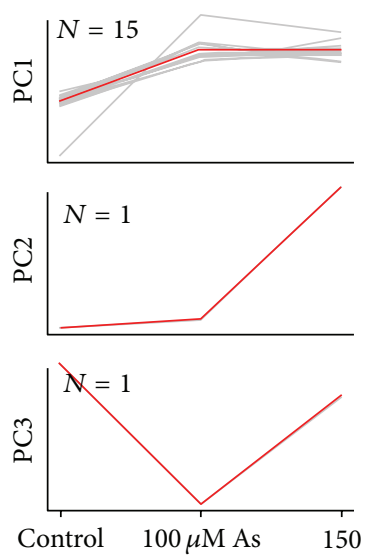

Centered intensity

Average

(c)

FIGURE 4: Multivariate analysis (PCA analysis) of control, 100 and $150 \mu \mathrm{M}$ As treatments using the ANOVA-based NIA array analysis tool. (a) Dendrogram showing hierarchical clustering of biological replicates of the control and As treatments. The expression clusters are numbered from 1 to 5. (b) Two-dimensional PCA biplots showing associations between experimental groups and protein spots generated by principal component analysis (PCA). Experimental groups (left) and protein spots (right) were plotted in the first two component spaces. Spots that are clustered together on the biplot should have similar expression profiles. (c) Protein spot abundance clustering based on PCA. For each PC, two clusters of proteins were identified that were positively and negatively correlated with the PC. Protein clustering was performed sequentially starting from the first PC. Proteins that were already clustered with a PC were not included in the clusters associated with subsequent PCs. The different colors of the spots represent the average expression patterns of proteins. Proteins are more expressed in those tissues which are located in the same area of the graph. 

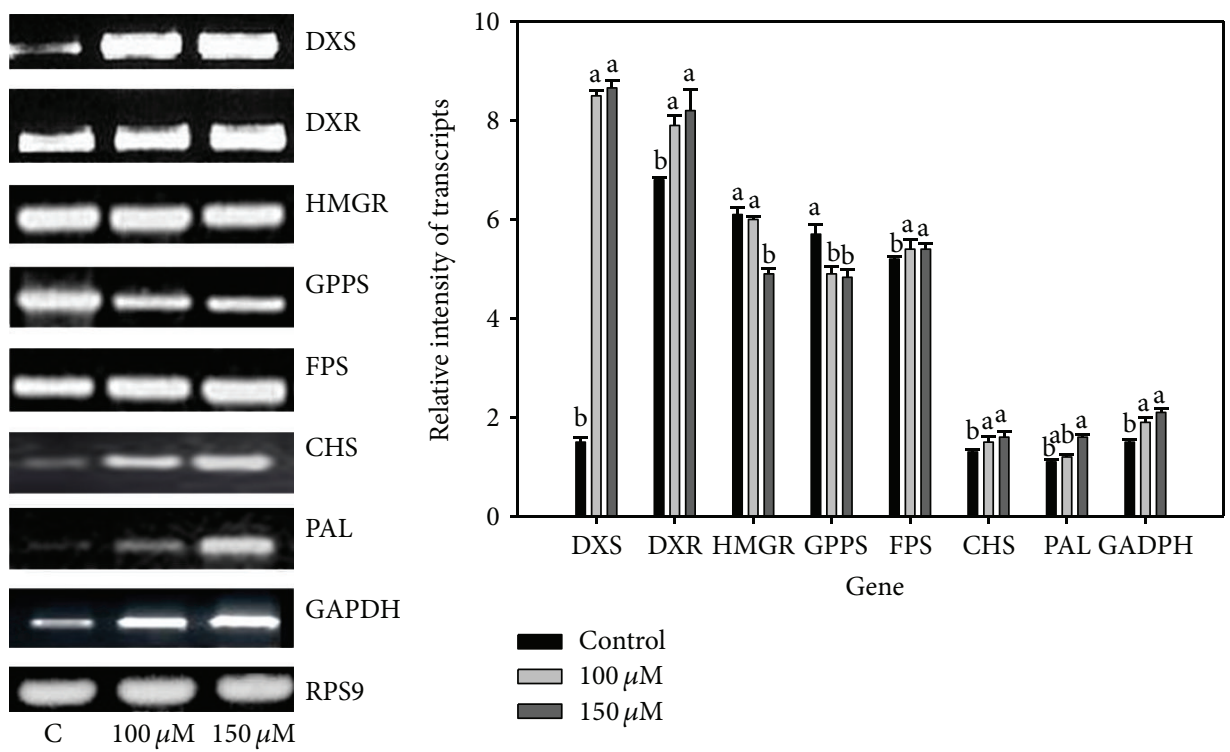

FIGURE 5: RT-PCR analysis of selected protein genes of flavonoid and artemisinin biosynthetic pathway. The experiment was repeated thrice. Ribosomal protein S9 (RPS9) was used as an internal control. DXS: 1-deoxy-d-xylulose 5-phosphate synthase; DXR: 1-deoxy-d-xylulose 5-phosphate reductoisomerase; HMGR: 3-hydroxy-3-methylglutaryl coenzyme A reductase; GPPS: geranyl pyrophosphate synthase; FPS: farnesyl diphosphate synthase; CHS: chalcone synthase; PAL: phenyl ammonia lyase; GAPDH: glyceraldehyde-3-phosphate dehydrogenase.
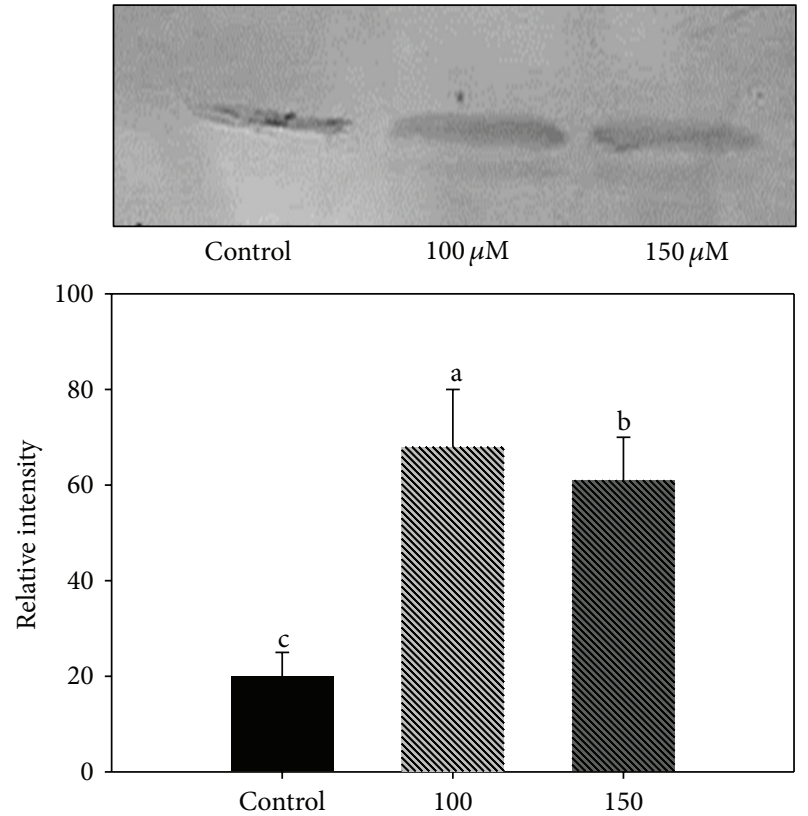

Figure 6: Western blot of PCS protein after treatment with 100 and $150 \mu \mathrm{M}$ As concentrations. Protein separated by SDS-PAGE, electroblotted onto a PVDF membrane, and cross-reacted with primary antibody (anti-PCS antibody).

the mechanism of As tolerance of A. annua, a medicinal plant whose genome has not yet been sequenced. Although 46 proteins identified by MALDI-TOF/MS/MS and MS-BLAST analyses represent only a very small fraction of $A$. annua leaf proteome, some novel As stress responsive proteins appear involved in cellular homeostasis and survival of A. annua plants under As stress.

4.1. As Regulates Plant Architecture and Flowering Time in A. annua. The alterations observed in inflorescence branching patterns, vegetative axillary shoot development, and flowering time in As treated $A$. апnи clearly indicate that these changes in plant form may arise, at least in part, due to change in expression pattern of conserved regulators or proteins. It is quite likely that the early onset of flowering and the increased number of florets and capitulum size in As treated A. апnиа were due to the significant accumulation of LEAFY- (LFY) like protein, a plant-specific transcription factor involved in growth, development [53], and flowering in Arabidopsis [54], first time observed under As stress. Furthermore, the red coloration of the leaf apex and shoots of $150 \mu \mathrm{M}$ As treated A. annua plants could be due to transient accumulation of anthocyanin pigments below the leaf epidermis. This finding is supported by an increased accumulation of chalcone synthase, involved in the production of secondary metabolites and pigments such as flavonoids and anthocyanin as also observed in As-stressed plants [55].

4.2. Photosynthetic Apparatus under As Stress. The physiological traits monitored revealed contrastingly differences under 100 and $150 \mu \mathrm{M}$ As treatments. While PSI activity, transpiration rate, ATP, and NADPH contents of $100 \mu \mathrm{M}$ As treated $A$. апnua plants showed an increase over the control values, a decrease for these parameters was recorded at $150 \mu \mathrm{M}$ As treatments. On the other hand, PSII activity registered decline under both the treatments, this being more pronounced at $150 \mu \mathrm{M}$ As treatments. The $F_{v} / F_{m}$ ratio, considered as indicator of the photochemical processes in 


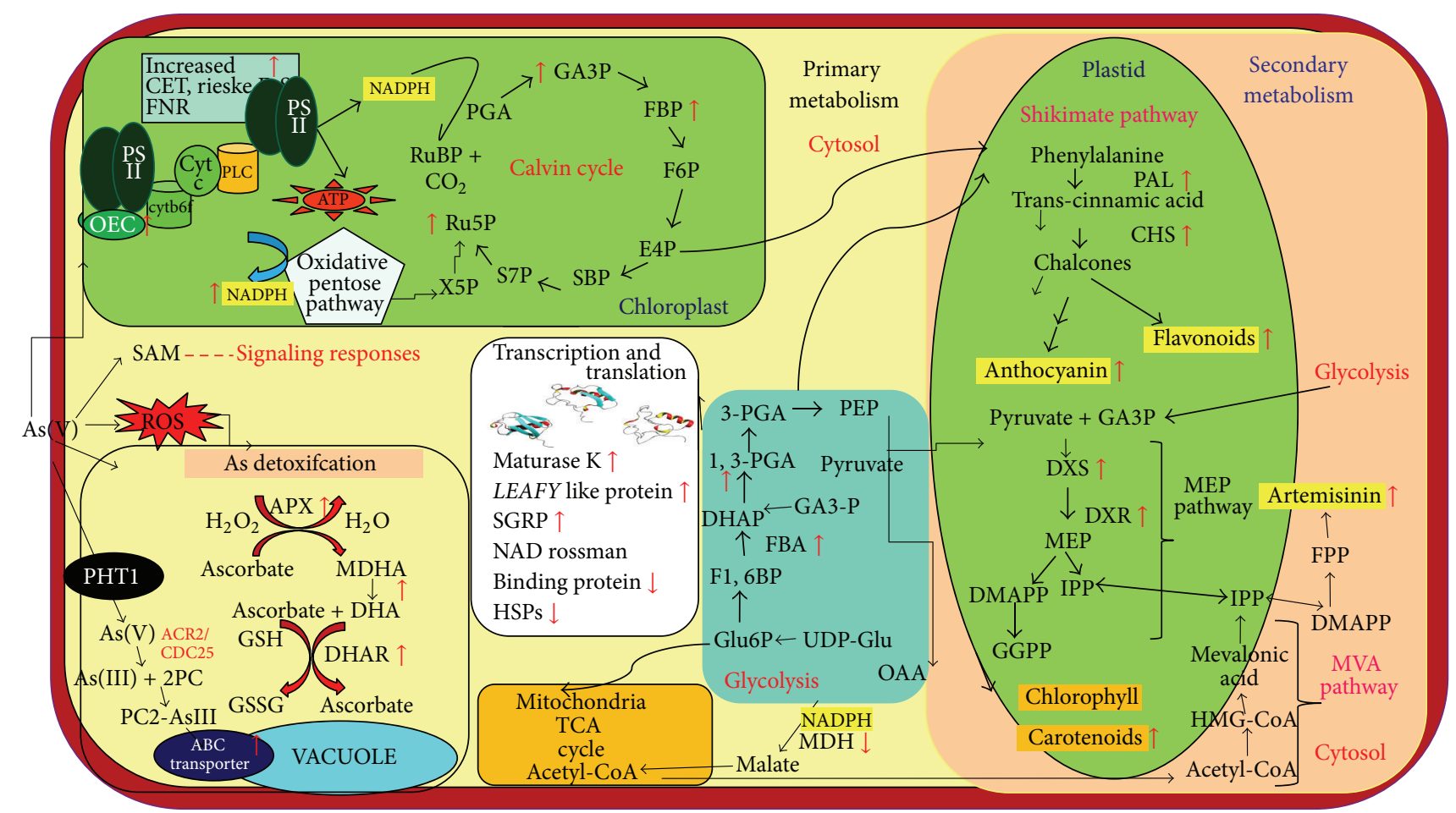

FIGURE 7: Hypothetical model depicting As tolerance and interactive protein network between primary and secondary metabolism in Artemisia annua.

photosystem 2 (PSII), depicted only a minor inhibition at $100 \mu \mathrm{M}$ but severe reduction under $150 \mu \mathrm{M}$ As treatments. Above findings were supported by the protein data having increased abundance of ATP synthase $\alpha$ subunit, rieske protein, and ferredoxin-NADP reductase (FNR) under $100 \mu \mathrm{M}$ As treatments, suggesting their likely role in As tolerance. Moreover, this enhancement unswervingly indicates operation of Fd-dependent cyclic electron transport (CET) in the test organism. In general, plants exposed to abiotic stresses show downregulation of linear electron flow (LEF) and activation of cyclic electron transport (CET) when linear electron flow becomes saturated $[56,57]$. It could be anticipated that under $100 \mu \mathrm{M}$ As treatment the LEF is partially replaced by CET around PSI and the upregulated CET in turn provides energy to the Calvin cycle [58] thereby meeting the energy demand. Appreciable increase in NADPH content seems justified in view of its requirement as reducing equivalents during $\mathrm{CO}_{2}$ fixation on one hand and maintaining a ratio of reduced glutathione for scavenging ROS. By contrast, under $150 \mu \mathrm{M}$ As treatments, the down regulated FNR disrupts CET. The electrons so accumulated suppress the charge separation of PSII reaction centre leading to damage of PSII as attested by the results of decreased $F_{v} / F_{m}$ ratios and decreased ATP content (Table 2, Figure 7). Four proteins of chlorophyll $\mathrm{a} / \mathrm{b}$ binding category (CP26 in PS II) displayed a mixed expression under 100 and $150 \mu \mathrm{M}$ As treatments. Altered levels of multiple forms of this protein have been reported in rice seedling under high temperature [59] and $\mathrm{H}_{2} \mathrm{O}_{2}$ stress
[60]. Another protein (spot 11) identified as chloroplast PS I type III chlorophyll $\mathrm{a} / \mathrm{b}$ binding protein was increased in $100 \mu \mathrm{M}$ As treatment. This may confer enhanced resistance of PSI as known for Hordeum vulgare against boron stress [61]. While (OECP2) protein spot 4 (intact) depicted increased relative abundance, the protein (spot 5) BLAST identified as oxygen-evolving complex protein (OECl) was decreased under both treatments. OECP2 are manganese stabilizing proteins playing crucial roles in photosystem II stability [41], their decreased accumulation supports the damaged PSII under As treatments. A marked increase in P protein subunit of glycine associated with photorespiration was found in $150 \mathrm{mM}$ As-stressed plants. Its overexpression stimulated photorespiration in Anabaena sp. under As stress [41]. These results clearly demonstrated that inhibition of photosynthetic rate in $150 \mu \mathrm{M}$ As treated A. annua was not the consequence of stomatal closure (reflected by high intercellular $\mathrm{CO}_{2}$ value) hence $\mathrm{CO}_{2}$ limitation may not be the real cause for reduced carbon assimilation rates. The decrease in assimilation rates could be due to low ATP and NADPH contents (Table 2) and consequent impairment of the photosynthesis $[47,62]$. Furthermore, the photosynthetic rate is known to weaken in the presence of heavy metals due to alterations in the active site of rubisco subunits $[63,64]$. By contrast, PSI complex machinery might be envisioned to support the damaged PSII and maintain NADPH pool in $100 \mu \mathrm{M}$ As treated plants as observed in As-tolerant cordgrass Spartina densiflora [65] and Ricinus communis [66]. 
4.3. Metabolic Networks under As Stress. Of the 15 identified proteins of the metabolic pathways like PLA, FBA class I, GAPDH, RuBP-5-P, TPI, and CA were increased in $100 \mu \mathrm{M}$ As treatment except for TK and RuBisCO activase. This finds support from Pandey et al. [41], where TK was decreased in abundance under As stress. Transketolase is a universal amphibolic enzyme catalyzing reactions in the Calvin cycle and the oxidative pentose pathway producing erythrose-4phosphate, leading to phenylpropanoid metabolism. Thus, any change in its abundance is expected to affect both photosynthetic carbon assimilation and secondary metabolism in plants. Despite a decrease in the abundance of transketolase in As treated plants neither Calvin cycle nor secondary metabolite synthesis (artemisinin, carotenoid, etc.) reflected any downregulation. This indicates the likely complementation of its role by some other enzymes. Henkes et al. [67] reported that Arabidopsis TK shares 23\% identity with DXS which depicted increased expression under decreased TK activity. Further, TK has been reported to be a DXS like protein [68] and hence speculated to play a role similar to transketolase. An in silico analysis of TK showed 38\% homology with DXS in A. annua and RT-PCR analysis revealed a significant transcript in As treated $A$. annua, which together support our above speculation (Figure 5). Of the three protein species corresponding to chloroplastic CA, two appeared as products of the same gene (spots 17 and 27) whereas the third one (spot 40) was different. An increased accumulation of carbonic anhydrase may be required for interconversion of $\mathrm{CO}_{2}$ and $\mathrm{HCO}_{3}{ }^{2}$ - and is thought to play a role in photosynthetic carbon assimilation as known in Arabidopsis [69] and other C3 plants [70, 71]. The increased abundance of various isoforms of FBA, GAPDH, and TPI clearly indicates the activation of the glycolytic pathway under As stress. FBA reversibly catalyzes the conversion of fructose 1, 6-bis phosphate (FBP) to GAP and dihydroxy acetone 3-phosphate (DHAP). During stress, GAP and FBP may be converted to glucose 6-phosphate for reentry into the PPP for NADPH synthesis. In the light of the reports of Pandey et al. [41], one is tempted to presume that enhanced expression of FBA maintained the glycolysis, PPP, and turnover rate of Calvin cycle. In contrast to the report of Ahsan et al. [20], significant accumulation of three isoforms of glyceraldehyde3P-dehydrogenase (GAPDH) was noticed. GAPDH detoxifies As using arsenate instead of phosphate converting glyceraldehyde 3-phosphate into 1-arseno-3-phospho-glycerate. Enhanced expression of GAPDH has also been detected in Pteris under As stress [24] rice seedlings under drought, submergence, and ABA treatment [72]. These findings imply that increased accumulation of GAPDH may contribute to abiotic stress tolerance in plant. Of particular interest was the cytoplasmic $\mathrm{MDH}$ depicting significant accumulation under $150 \mu \mathrm{M}$ but no change under $100 \mu \mathrm{M}$ As treatment. This is conceivable because As stress leads to phosphate (Pi) starvation in plants (Supplementary Table S1). Though arsenic substitutes for phosphorus in the plants, it cannot function like phosphate, hence plants realize phosphate deficiency [73]. Under these situations, plants ought to cope up with Pi deficiency. Taken together, these results suggest an increased turnover of $\mathrm{CO}_{2}$ assimilating pathway and redox energy production in the $100 \mu \mathrm{M}$ As treated plants which are required for survival under downregulated photosynthetic rate. In contrast, decrease in carbon metabolism proteins associated with breakdown of energy generation results in failure of the plants to cope up with $150 \mu \mathrm{M}$ As toxicity.

\subsection{Regulation of Antioxidant Machinery, Protein Metabolism,} and Transport under As Stress. Two antioxidant proteins identified in this study include dehydroascorbate peroxidase and ascorbate peroxidase in $100 \mu \mathrm{M}$ As treatments. While DHAR (spot 18) has been reported to offer tolerance against oxidative stress [74], APX catalyses the reduction of $\mathrm{H}_{2} \mathrm{O}_{2}$ to water in ascorbate-glutathione cycle [75]. Increased abundance of APX under stress is nicely documented in earlier proteomic works $[76,77]$. It is quite likely that the upregulated ascorbate-glutathione cycle regulates excess ROS generated at PSII thereby offering tolerance in $100 \mu \mathrm{M}$ As treated plants. This is in accordance with the findings of Rai et al. [11]. Three proteins belonging to transcriptional regulator category, namely, glycine rich RNA binding protein, maturase $\mathrm{K}$, and $L E A F Y$ like protein displayed analogous abundance in 100 and $150 \mu \mathrm{M}$ As treatments, with a slightly higher level in $150 \mu \mathrm{M}$ As. Glycine rich RNA binding proteins are implicated in osmotic, cold stress, and RNA splicing activity [78], and maturase $\mathrm{K}$ functions like a ribosomal protein with RNA chaperone activity [79]. Increased accumulation of these proteins suggest their conceivable role in overcoming the As stress. Another interesting observation was upregulated protein synthesis in $A$. annua under As stress. Of the four proteins belonging to the protein metabolism category, the rossmann $\mathrm{NAD}(\mathrm{P})$ fold, a structural motif found in nucleotide binding proteins [80], was increased under both As treatments, whereas ribosomal L 12 was increased in $100 \mu \mathrm{M}$ but decreased in $150 \mu \mathrm{M}$ As treatments. In contrast to the above, two molecular chaperones, Hsp70 and chloroplast protease were decreased under both As treatments. Significant down regulation of Hsp70 suggests it to be the key target under As stress as observed in Poplar trees under Cd stress [17] and needs further investigation.

Of particular interest are the multidrug resistanceassociated proteins (MRPs), a subclass of ATP-binding cassette $(A B C)$ transporters with a hypothetical role in As extrusion in plant. Our previous finding [11] impelled to check the role of pcs gene in As detoxification. The upregulated (1.5fold) mdr-like ABC transporter and pcs gene (as confirmed by Western blot analysis, Figure 6) under $100 \mu \mathrm{M}$ As suggest that detoxification was brought about by reduction of $\mathrm{As}(\mathrm{V})$ to As(III) and sequestration with phytochelatin. The increased abundance of (ABC) transporters has also been reported in Comamonas sp. under As stress [81]. Another interesting observation was the increased accumulation of S-adenosyl methionine synthase (SAMS), known to act as a signaling molecule and protects cells from arsenic stress by forming Sadenosyl-methionine [20]. Furthermore, in the light of the report of Noriega et al. [82] that SAM protects cells from deleterious effects of cadmium, its increased accumulation under $100 \mu \mathrm{M}$ As treatment seems justified. 
4.5. Hypothetical Model Depicting As Tolerance and Interaction between Primary and Secondary Metabolism in A. annua. Taking recourse to 39 As-responsive proteins as well as the data available in the literature, a protein network model has been proposed. This network consists of several functional components, including ROS production and scavenging, electron transport chain, protein metabolism, photosynthesis, energy supply, and biosynthesis of signaling molecules (Figure 7). The model clearly shows that As(V) may be taken up by the test plants through phosphate transporter Phtl and reduced to arsenite As(III) by arsenate reductase (ACR2/CDC 25) in the cell. As(III) is rapidly complexed with soluble thiols and phytochelatins. Upon binding to phytochelatins (PCs), PC2-As(III) complexes are deposited into the vacuole by $\mathrm{ABC}$ transporters. This is clearly reflected by increased phytochelatin content and transcript of pcs gene under As stress. To cope up with the As stress, A. annua plants in turn activate their antioxidative and photosynthetic machineries. Two groups of proteins identified in multiple isoforms are chlorophyll a, b binding protein as well as OEC of PSII. OEC appears to be involved in the oxidation of water molecules to form molecular oxygen and ATP production via proton pumps. The excess electrons are transferred to oxygen at PSI or via Mehler reaction. In order to protect PSII from ROS, As-stressed plants augment excess electron removal by activating ascorbate-glutathione cycle such as APX and DHAR. An increased abundance of FBA, Ru5P, ALD, and CA (Table 3) points not only enhanced turnover of $\mathrm{CO}_{2}$, assimilating pathway but also augmentation in ATP and NADPH synthesis. This was clearly reflected by an increased cyclic electron flow around PSI through increased accumulation of Fd-NADP reductase, rieske-Fes, and ATP synthase. The increased ATP and redox energy support enhanced $\mathrm{CO}_{2}$ assimilation. The enhanced glycolysis provides not only reducing power required for As detoxification and repair but also precursors for biosynthesis of aromatic amino acid, flavonoid, and anthocyanin (via shikimate pathway) and artemisinin (via MEP pathway). Interestingly, two intermediates of glycolysis, GAPDH and pyruvate, are direct substrates of the DXP synthase. The upregulation of GAPDH on 2DE gel indicates persistent triose supply for the synthesis of artemisinin, anthocyanin, and carotenoids. Furthermore, the upregulated Calvin cycle and PPP produce erythrose-4-phosphate, a precursor for the shikimate pathway leading to phenylpropanoid metabolism. The rapid consumption of glyceraldehyde-3-P and other primary metabolites requiring continuous replenishment of carbon intermediates may in turn be provided by ribulose5-P (with 2-fold accumulation on 2DE gel). Presence of only one protein (CHS) belonging to a flavonoid biosynthetic pathway may be due probably to limited number of protein spots analyzed. The network connection between primary and secondary metabolism of $A$. annua measured by the transcript of enzymes of flavonoid and artemisinin biosynthetic pathway such as DXS, DXR, FPS, HMGR, GPPS, CHS, and PAL indicated their fine regulatory network.

\section{Conclusions}

Of the different proteins identified in this study, proteins of photosynthesis and carbon metabolism appear as possible candidates for augmenting As tolerance in A. annua, although the exact mechanism of tolerance remains to be investigated. Our results also suggest that ABC-transporter like protein may be involved in As sequestration into vacuoles as the final detoxification step. Data obtained in this study provide clues to the molecular aspects of As tolerance, as well as in development of As resistant crop varieties through plant breeding and biotechnological interventions.

\author{
Abbreviations \\ ANOVA: Analysis of variance \\ CBB: Coomassie Brilliant Blue \\ CHAPS: 3-(3-Cholamidopropyl) \\ dimethylammonio-1-propane sulfonate \\ FBA: $\quad$ Fructose bisphosphatase aldolase class I \\ GAPDH: Glyceraldehyde-3-phosphate \\ dehydrogenase \\ Ru-5-P: Ribulose-5-phosphate, 3-epimerase \\ CA: Carbonic anhydrase \\ TK: Transketolase \\ $\mathrm{MDH}$ : Malate dehydrogenase \\ TPI: $\quad$ Triose phosphate isomerase \\ GRP: Glycine-rich RNA binding protein \\ DMAPP: Dimethylallyl diphosphate \\ DXS: 1-Deoxy-d-xylulose 5-phosphate synthase \\ DXR: 1-Deoxy-d-xylulose 5-phosphate \\ reductoisomerase \\ FPS: $\quad$ Farnesyl diphosphate synthase \\ HMGR: 3-Hydroxy-3-methylglutaryl coenzyme A \\ reductase \\ GPPS: Geranyl pyrophosphate synthase \\ IPP: isopentenyl diphosphate \\ MEP: 2-C-methyl-d-erythritol-4-phosphate \\ MVA: Mevalonic acid \\ CHS: Chalcone synthase \\ PAL: Phenyl ammonia lyase \\ PCA: Principal component analysis \\ FDR: False discovery rate.
}

\section{Conflict of Interests}

The authors declare that there is no conflict of interests regarding the publication of this paper.

\section{Acknowledgments}

Rashmi Rai, Sarita Pandey, and Alok Shrivastava thank the Council of Scientific and Industrial Research for Senior Research Fellowship. Professor L. C. Rai FNA, Coordinator Centre of Advanced Study in Botany, Banaras Hindu University, is gratefully acknowledged for liberally providing the facilities for proteomic work as well as for his critical reading of the paper and valuable suggestions. The authors thank 
Mr. Sanjeev Kumar of BioCOS Life Sciences Private Limited, Bangalore, India, for multivariate analysis.

\section{References}

[1] S. A. Adejump, A. O. Togun, J. A. Adediran, and M. B. Ogundiran, "In-situ remediation of heavy metal contaminated soil using Mexican Sunflower (Tithonia densiflora) and Cassava waste compost," World Journal of Agricultural Sciences, vol. 7, pp. 224-233, 2011.

[2] D. Chakraborti, S. C. Mukherjee, S. Pati et al., "Arsenic groundwater contamination in Middle Ganga Plain, Bihar, India: a future danger?" Environmental Health Perspectives, vol. 111, no. 9, pp. 1194-1201, 2003.

[3] J. F. Ma, N. Yamaji, N. Mitani et al., "Transporters of arsenite in rice and their role in arsenic accumulation in rice grain," Proceedings of the National Academy of Sciences of the United States of America, vol. 105, no. 29, pp. 9931-9935, 2008.

[4] X. Cao, L. Q. Ma, and C. Tu, "Antioxidative responses to arsenic in the arsenic-hyperaccumulator Chinese brake fern (Pteris vittata L.)," Environmental Pollution, vol. 128, no. 3, pp. 317-325, 2004.

[5] J. R. Rofkar, D. F. Dwyer, and J. M. Frantz, "Analysis of arsenic uptake by plant species selected for growth in northwest Ohio by inductively coupled plasma-optical emission spectroscopy," Communications in Soil Science and Plant Analysis, vol. 38, no. 17-18, pp. 2505-2517, 2007.

[6] W. Wang, Y. Wang, Q. Zhang, Y. Qi, and D. Guo, "Global characterization of Artemisia annua glandular trichome transcriptome using 454 pyrosequencing," BMC Genomics, vol. 10, article 465, 2009.

[7] R. K. Haynes, "From artemisinin to new artemisinin antimalarials: biosynthesis, extraction, old and new derivatives, stereochemistry and medicinal chemistry requirements," Current Topics in Medicinal Chemistry, vol. 6, no. 5, pp. 509-537, 2006.

[8] T. Efferth, M. R. Romero, D. G. Wolf, T. Stamminger, J. J. G. Marin, and M. Marschall, "The antiviral activities of artemisinin and artesunate," Clinical Infectious Diseases, vol. 47, no. 6, pp. 804-811, 2008.

[9] T. Efferth, "Willmar Schwabe award 2006: antiplasmodial and antitumor activity of artemisinin-from bench to bedside," Planta Medica, vol. 73, no. 4, pp. 299-309, 2007.

[10] WHO, WHO Monograph on Good Agricultural and Collection Practices (GACP) for Artemisia annua L., WHO, Geneva, Switzerland, 2006.

[11] R. Rai, S. Pandey, and S. P. Rai, "Arsenic-induced changes in morphological, physiological, and biochemical attributes and artemisinin biosynthesis in Artemisia annua, an antimalarial plant," Ecotoxicology, vol. 20, no. 8, pp. 1900-1913, 2011.

[12] R. D. Tripathi, P. Tripathi, S. Dwivedi et al., "Arsenomics: omics of arsenic metabolism in plants," Frontiers in Physiology, vol. 3, article 275, 2012.

[13] K. Kosová, P. Vítámvás, I. T. Prášil, and J. Renaut, "Plant proteome changes under abiotic stress-contribution of proteomics studies to understanding plant stress response," Journal of Proteomics, vol. 74, no. 8, pp. 1301-1322, 2011.

[14] S. Bohler, M. Bagard, M. Oufir et al., "A DIGE analysis of developing poplar leaves subjected to ozone reveals major changes in carbon metabolism," Proteomics, vol. 7, no. 10, pp. 1584-1599, 2007.
[15] X. Zang and S. Komatsu, "A proteomics approach for identifying osmotic-stress-related proteins in rice," Phytochemistry, vol. 68, no. 4, pp. 426-437, 2007.

[16] F. Han, H. Chen, X. J. Li, M. F. Yang, G. S. Liu, and S. H. Shen, "A comparative proteomic analysis of rice seedlings under various high-temperature stresses," Biochimica et Biophysica Acta-Proteins and Proteomics, vol. 1794, no. 11, pp. 1625-1634, 2009.

[17] P. Kieffer, J. Dommes, L. Hoffmann, J. F. Hausman, and J. Renaut, "Quantitative changes in protein expression of cadmium-exposed poplar plants," Proteomics, vol. 8, no. 12, pp. 2514-2530, 2008.

[18] R. Requejo and M. Tena, "Proteome analysis of maize roots reveals that oxidative stress is a main contributing factor to plant arsenic toxicity," Phytochemistry, vol. 66, no. 13, pp. 1519-1528, 2005.

[19] R. Requejo and M. Tena, "Maize response to acute arsenic toxicity as revealed by proteome analysis of plant shoots," Proteomics, vol. 6, pp. 156-162, 2006.

[20] N. Ahsan, D. G. Lee, I. Alam et al., "Comparative proteomic study of arsenic-induced differentially expressed proteins in rice roots reveals glutathione plays a central role during As stress," Proteomics, vol. 8, no. 17, pp. 3561-3576, 2008.

[21] N. Ahsan, D. G. Lee, K. H. Kim et al., "Analysis of arsenic stress-induced differentially expressed proteins in rice leaves by two-dimensional gel electrophoresis coupled with mass spectrometry," Chemosphere, vol. 78, no. 3, pp. 224-231, 2010.

[22] I. Duquesnoy, P. Goupil, I. Nadaud, G. Branlard, A. PiquetPissaloux, and G. Ledoigt, "Identification of Agrostis tenuis leaf proteins in response to $\mathrm{As}(\mathrm{V})$ and $\mathrm{As}(\mathrm{III})$ induced stress using a proteomics approach," Plant Science, vol. 176, no. 2, pp. 206-213, 2009.

[23] E. Bona, C. Cattaneo, P. Cesaro et al., "Proteomic analysis of Pteris vittata fronds: two arbuscular mycorrhizal fungi differentially modulate protein expression under arsenic contamination," Proteomics, vol. 10, no. 21, pp. 3811-3834, 2010.

[24] E. Bona, F. Marsano, N. Massa et al., "Proteomic analysis as a tool for investigating arsenic stress in Pteris vittata roots colonized or not by arbuscular mycorrhizal symbiosis," Journal of Proteomics, vol. 74, no. 8, pp. 1338-1350, 2011.

[25] N. Stoeva and T. Bineva, "Oxidative changes and photosynthesis in oat plants grown in As contaminated soil," Bulgarian Journal of Plant Physiology, vol. 29, pp. 87-95, 2003.

[26] E. Miteva and M. Merakchiyska, "Response of chloroplasts and photosynthetic mechanism of bean plants to excess arsenic in soil," Bulgarian Journal of Agricultural Science, vol. 8, pp. 151156, 2002.

[27] D. R. Hoagland and D. I. Arnon, "The water-culture method for growing plants without soil," California Agricultural Experiment Station, vol. 347, pp. 1-3, 1950.

[28] S. Ahamed, M. Kumar Sengupta, A. Mukherjee et al., "Arsenic groundwater contamination and its health effects in the state of Uttar Pradesh (UP) in upper and middle Ganga plain, India: a severe danger," Science of the Total Environment, vol. 370, no. 2-3, pp. 310-322, 2006.

[29] T. Roychowdhury, T. Uchino, H. Tokunaga, and M. Ando, "Survey of arsenic in food composites from an arsenic-affected area of West Bengal, India," Food and Chemical Toxicology, vol. 40, no. 11, pp. 1611-1621, 2002.

[30] C. H. Fiske and Y. Subbarow, "The colorimetric determination of phosphorus," The Journal of Biological Chemistry, vol. 66, pp. 375-400, 1925. 
[31] C. Larsson and T. Olssonl, "Firefly assay of adenine nucleotides from algae: comparison of extraction methods," Plant and Cell Physiology, vol. 20, no. 1, pp. 145-155, 1979.

[32] D. A. Smyth and W. M. Dugger, "Cellular changes during boron-deficient culture of the diatom Cylindrotheca fusiformis," Physiologia Plantarum, vol. 51, no. 1, pp. 111-117, 1981.

[33] S. R. Mishra and S. C. Sabat, "Effect of calcium ion on Hydrilla verticillata thylakoid membrane $\mathrm{O}_{2}$ evolution," Indian Journal of Biochemistry and Biophysics, vol. 32, no. 2, pp. 94-99, 1995.

[34] N. Atal, P. P. Saradhi, and P. Mohanty, "Inhibition of the chloroplast photochemical reactions by treatment of wheat seedlings with low concentrations of cadmium: analysis of electron transport activities and changes in fluorescence yield," Plant and Cell Physiology, vol. 32, no. 7, pp. 943-951, 1991.

[35] D. I. Arnon, "Copper enzymes in isolated chloroplast: polyphenol oxidase in beet (Beta vulgaris)," Plant Physiology, vol. 24, no. 1, pp. 1-15, 1949.

[36] S. S. Zhao and M. Y. Zeng, "Spectrometric high-pressure liquid chromatographic studies on analytical chemistry of Qinghaosu," Planta Medica, vol. 3, pp. 233-237, 1985.

[37] H. Lange, W. Shropshire, and H. Mohr, "An analysis of phytochrome mediated anthocyanin synthesis," Plant Physiology, vol. 47, no. 5, pp. 649-655, 1971.

[38] A. Bette and U. Kutschera, "Pigment accumulation and photosynthesis in developing rye coleoptiles," Botanica Acta, vol. 109, no. 3, pp. 194-198, 1996.

[39] D. A. Sims and J. A. Gamon, "Relationships between leaf pigment content and spectral reflectance across a wide range of species, leaf structures and developmental stages," Remote Sensing of Environment, vol. 81, no. 2-3, pp. 337-354, 2002.

[40] M. M. Bradford, "A rapid and sensitive method for the quantitation of microgram quantities of protein utilizing the principle of protein dye binding," Analytical Biochemistry, vol. 72, no. 1-2, pp. 248-254, 1976.

[41] S. Pandey, R. Rai, and L. C. Rai, "Proteomics combines morphological, physiological and biochemical attributes to unravel the survival strategy of Anabaena sp. PCC7120 under arsenic stress," Journal of Proteomics, vol. 75, no. 3, pp. 921-937, 2012.

[42] A. Shevchenko, M. Wilm, O. Vorm, and M. Mann, "Mass spectrometric sequencing of proteins from silver-stained polyacrylamide gels," Analytical Chemistry, vol. 68, no. 5, pp. 850858, 1996.

[43] Y. Mishra, P. Bhargava, N. Chaurasia, and L. C. Rai, "Proteomic evaluation of the non-survival of Anabaena doliolum (Cyanophyta) at elevated temperatures," European Journal of Phycology, vol. 44, no. 4, pp. 551-565, 2009.

[44] A. A. Sharov, D. B. Dudekula, and M. S. H. Ko, "A webbased tool for principal component and significance analysis of microarray data," Bioinformatics, vol. 21, no. 10, pp. 2548-2549, 2005.

[45] O. Björkman and B. Demmig, "Photon yield of $\mathrm{O}_{2}$ evolution and chlorophyll fluorescence characteristics at $77 \mathrm{~K}$ among vascular plants of diverse origins," Planta, vol. 170, no. 4, pp. 489-504, 1987.

[46] K. Maxwell and G. N. Johnson, "Chlorophyll fluorescence-a practical guide," Journal of Experimental Botany, vol. 51, no. 345, pp. 659-668, 2000.

[47] Z. Krupa and M. Moniak, "The stage of leaf maturity implicates the response of the photosynthetic apparatus to cadmium toxicity," Plant Science, vol. 138, no. 2, pp. 149-156, 1998.
[48] S. P. Yan, Q. Y. Zhang, Z. C. Tang, W. A. Su, and W. N. Sun, "Comparative proteomic analysis provides new insights into chilling stress responses in rice," Molecular and Cellular Proteomics, vol. 5, no. 3, pp. 484-496, 2006.

[49] Q. Jiang, H. Chen, X. Pan et al., "Proteomic analysis of wheat (Triticum aestivum L.) hybrid necrosis," Plant Science, vol. 175, no. 3, pp. 394-401, 2008.

[50] J. M. Abercrombie, M. D. Halfhill, P. Ranjan et al., "Transcriptional responses of Arabidopsis thaliana plants to As (V) stress," BMC Plant Biology, vol. 8, article 87, 2008.

[51] M. Bevan, I. Bancroft, E. Bent et al., "Analysis of $1.9 \mathrm{Mb}$ of contiguous sequence from chromosome 4 of Arabidopsis thaliana," Nature, vol. 391, no. 6666, pp. 485-488, 1998.

[52] C. Xu, W. M. Garrett, J. Sullivan, and T. J. Caperna, "Separation and identification of soybean leaf proteins by two-dimensional gel electrophoresis and mass spectrometry," Phytochemistry, vol. 67, no. 22, pp. 2431-2340, 2006.

[53] Q. Meng, C. Zhang, F. Huang, J. Gai, and D. Yu, "Molecular cloning and characterization of a $L E A F Y$-like gene highly expressed in developing soybean seeds," Seed Science Research, vol. 17, no. 4, pp. 297-302, 2007.

[54] P. Han, B. García-Ponce, G. Fonseca-Salazar, E. R. AlvarezBuylla, and H. Yu, "AGAMOUS-LIKE 17, a novel flowering promoter, acts in a FT-independent photoperiod pathway," Plant Journal, vol. 55, no. 2, pp. 253-265, 2008.

[55] P. Catarecha, M. D. Segura, J. M. Franco-Zorrilla et al., "A mutant of the Arabidopsis phosphate transporter PHT1;1 displays enhanced arsenic accumulation," Plant Cell, vol. 19, no. 3, pp. 1123-1133, 2007.

[56] B. Dhir, P. Sharmila, and P. P. Saradhi, "Photosynthetic performance of Salvinia natans exposed to chromium and zinc rich wastewater," Brazilian Journal of Plant Physiology, vol. 20, no. 1, pp. 61-70, 2008.

[57] J. E. Backhausen, C. Kitzmann, P. Horton, and R. Scheibe, "Electron acceptors in isolated intact spinach chloroplasts act hierarchically to prevent over-reduction and competition for electrons," Photosynthesis Research, vol. 64, no. 1, pp. 1-13, 2000.

[58] J. K. Hurley, R. Morales, M. Martínez-Júlvez et al., "Structure-function relationships in Anabaena ferredoxin/ferredoxin:NADP ${ }^{+}$reductase electron transfer: insights from site-directed mutagenesis, transient absorption spectroscopy and X-ray crystallography," Biochimica et Biophysica Acta-Bioenergetics, vol. 1554, no. 1-2, pp. 5-21, 2002.

[59] F. Han, H. Chen, X. J. Li, M. F. Yang, G. S. Liu, and S. H. Shen, "A comparative proteomic analysis of rice seedlings under various high-temperature stresses," Biochimica et Biophysica Acta-Proteins and Proteomics, vol. 1794, no. 11, pp. 1625-1634, 2009.

[60] X. Y. Wan and J. Y. Liu, "Comparative proteomics analysis reveals an intimate protein network provoked by hydrogen peroxide stress in rice seedling leaves," Molecular and Cellular Proteomics, vol. 7, no. 8, pp. 1469-1488, 2008.

[61] A. E. Atik, G. O. Bozdağ, E. Akinci et al., "Proteomic changes during boron tolerance in barley (Hordeum vulgare) and the role of vacuolar proton-translocating ATPase subunit E," Turkish Journal of Botany, vol. 35, no. 4, pp. 379-388, 2011.

[62] M. Burzyński and G. Kłobus, "Changes of photosynthetic parameters in cucumber leaves under $\mathrm{Cu}, \mathrm{Cd}$, and $\mathrm{Pb}$ stress," Photosynthetica, vol. 42, no. 4, pp. 505-510, 2004. 
[63] A. Siedlecka and Z. Krupa, "Rubisco activity maintenance in environmental stress conditions-how many strategies," Cellular and Molecular Biology Letters, vol. 9, pp. 56-57, 2004.

[64] M. T. Domínguez, T. Marañón, J. M. Murillo, and S. RedondoGómez, "Response of Holm oak (Quercus ilex subsp. ballota) and mastic shrub (Pistacia lentiscus L.) seedlings to high concentrations of $\mathrm{Cd}$ and $\mathrm{Tl}$ in the rhizosphere," Chemosphere, vol. 83, no. 8, pp. 1166-1174, 2011.

[65] E. Mateos-Naranjo, L. Andrades-Moreno, and S. RedondoGómez, "Tolerance to and accumulation of arsenic in the cordgrass Spartina densiflora Brongn," Bioresource Technology, vol. 104, pp. 187-194, 2012.

[66] R. Mahmud, N. Inoue, S. Y. Kasajima et al., "Response of common buckwheat and castor oil plant against different levels of soil arsenic concentration: a comparative study," Fagopyrum, vol. 23, pp. 45-51, 2006.

[67] S. Henkes, U. Sonnewald, R. Badur, R. Flachmann, and M. Stitt, "A small decrease of plastid transketolase activity in antisense tobacco transformants has dramatic effects on photosynthesis and phenylpropanoid metabolism," Plant Cell, vol. 13, no. 3, pp. 535-551, 2001.

[68] M. Rohmer, M. Seemann, S. Horbach, S. Bringer-Meyer, and H. Sahm, "Glyceraldehyde 3-phosphate and pyruvate as precursors of isoprenic units in an alternative non-mevalonate pathway for terpenoid biosynthesis," Journal of the American Chemical Society, vol. 118, no. 11, pp. 2564-2566, 1996.

[69] F. J. Ferreira, C. Guo, and J. R. Coleman, "Reduction of plastid-localized carbonic anhydrase activity results in reduced Arabidopsis seedling survivorship," Plant Physiology, vol. 147, no. 2, pp. 585-594, 2008.

[70] L. E. Fridlyand and V. L. Kaler, "Possible $\mathrm{CO}_{2}$ concentrating mechanism in chloroplasts of C3 plants. Role of carbonic anhydrase," General Physiology and Biophysics, vol. 6, no. 6, pp. 617-636, 1987.

[71] P. Kieffer, S. Planchon, M. Oufir et al., "Combining proteomics and metabolite analyses to unravel cadmium stress-response in poplar leaves," Journal of Proteome Research, vol. 8, no. 1, pp. 400-417, 2009.

[72] M. A. Pillai, Z. Lihuang, and T. Akiyama, "Molecular cloning, characterization, expression and chromosomal location of OsGAPDH, a submergence responsive gene in rice (Oryza sativa L.)," Theoretical and Applied Genetics, vol. 105, no. 1, pp. 34-42, 2002.

[73] C. Tu and L. Q. Ma, "Effects of arsenic on concentration and distribution of nutrients in the fronds of the arsenic hyperaccumulator Pteris vittata L," Environmental Pollution, vol. 135, no. 2, pp. 333-340, 2005.

[74] Z. Wang, Y. Xiao, W. Chen, K. Tang, and L. Zhang, "Increased vitamin $\mathrm{C}$ content accompanied by an enhanced recycling pathway confers oxidative stress tolerance in Arabidopsis," Journal of Integrative Plant Biology, vol. 52, no. 4, pp. 400-409, 2010.

[75] Y. Nakano and K. Asada, "Hydrogen peroxide is scavenged by ascorbate-specific peroxidase in spinach chloroplasts," Plant and Cell Physiology, vol. 22, no. 5, pp. 867-880, 1981.

[76] K. Lee, D. W. Bae, S. H. Kim et al., "Comparative proteomic analysis of the short-term responses of rice roots and leaves to cadmium," Journal of Plant Physiology, vol. 167, no. 3, pp. 161168, 2010.

[77] R. Rakwal, G. K. Agrawal, and M. Yonekura, "Separation of proteins from stressed rice (Oryza sativa L.) leaf tissues by two-dimensional polyacrylamide gel electrophoresis: induction of pathogenesis-related and cellular protectant proteins by jasmonic acid, UV irradiation and copper chloride," Electrophoresis, vol. 20, no. 17, pp. 3472-3478, 1999.

[78] A. Mangeon, R. M. Junqueira, and G. Sachetto-Martins, "Functional diversity of the plant glycine-rich proteins superfamily," Plant Signaling and Behavior, vol. 5, no. 2, pp. 99-104, 2010.

[79] I. S. Minas, G. Tanou, M. Belghazi et al., "Physiological and proteomic approaches to address the active role of ozone in kiwifruit post-harvest ripening," Journal of Experimental Botany, vol. 637, pp. 2449-2464, 2012.

[80] N. S. Scrutton, A. Berry, and R. N. Perham, "Redesign of the coenzyme specificity of a dehydrogenase by protein engineering," Nature, vol. 343, no. 6253, pp. 38-43, 1990.

[81] Y. Zhang, Y. F. Ma, S. W. Qi et al., "Responses to arsenate stress by Comamonas sp. strain CNB-1 at genetic and proteomic levels," Microbiology, vol. 153, no. 11, pp. 3713-3721, 2007.

[82] G. O. Noriega, K. B. Balestrasse, A. Batlle, and M. L. Tomaro, "Cadmium induced oxidative stress in soybean plants also by the accumulation of $\delta$-aminolevulinic acid," BioMetals, vol. 20, no. 6, pp. 841-851, 2007. 

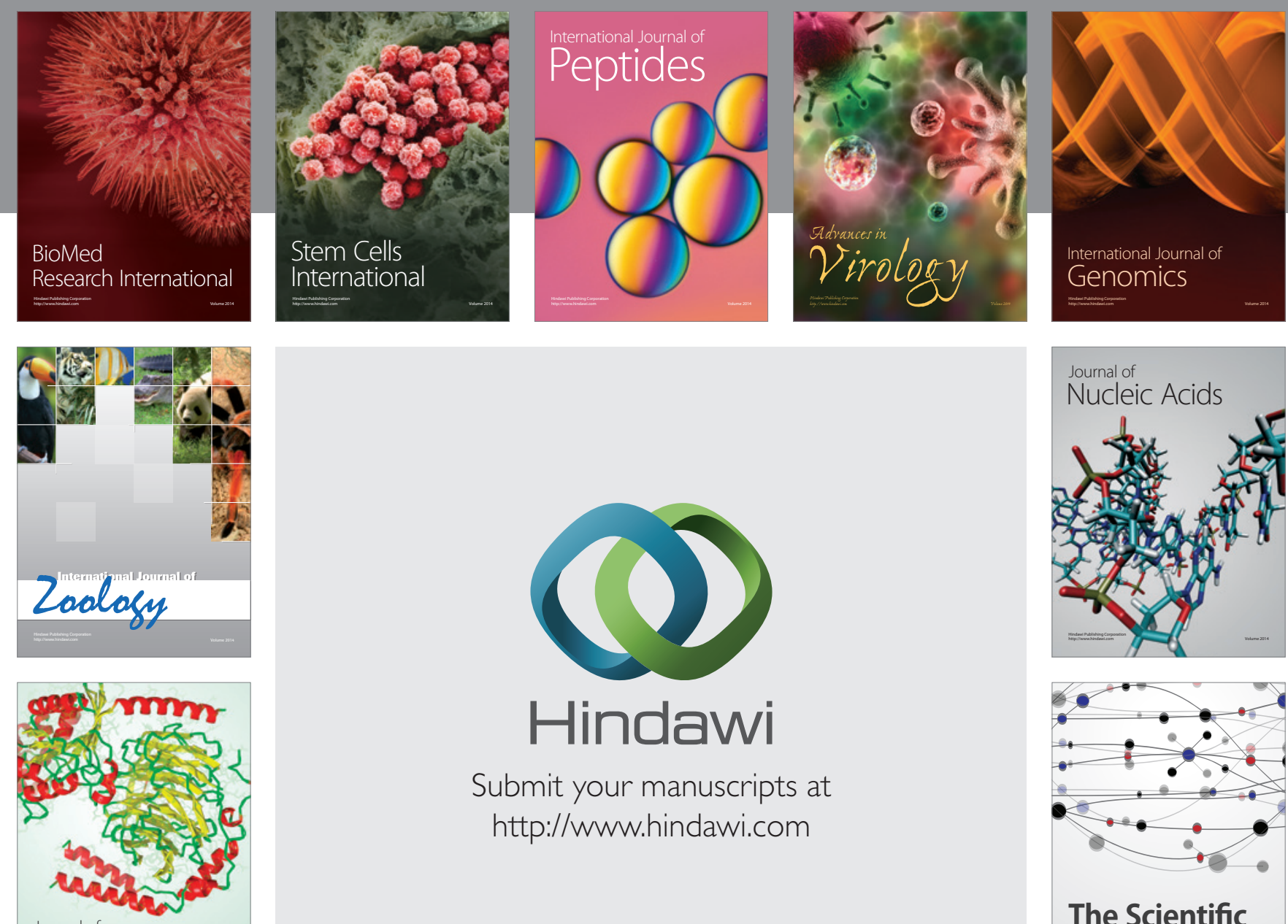

Submit your manuscripts at

http://www.hindawi.com

Journal of
Signal Transduction
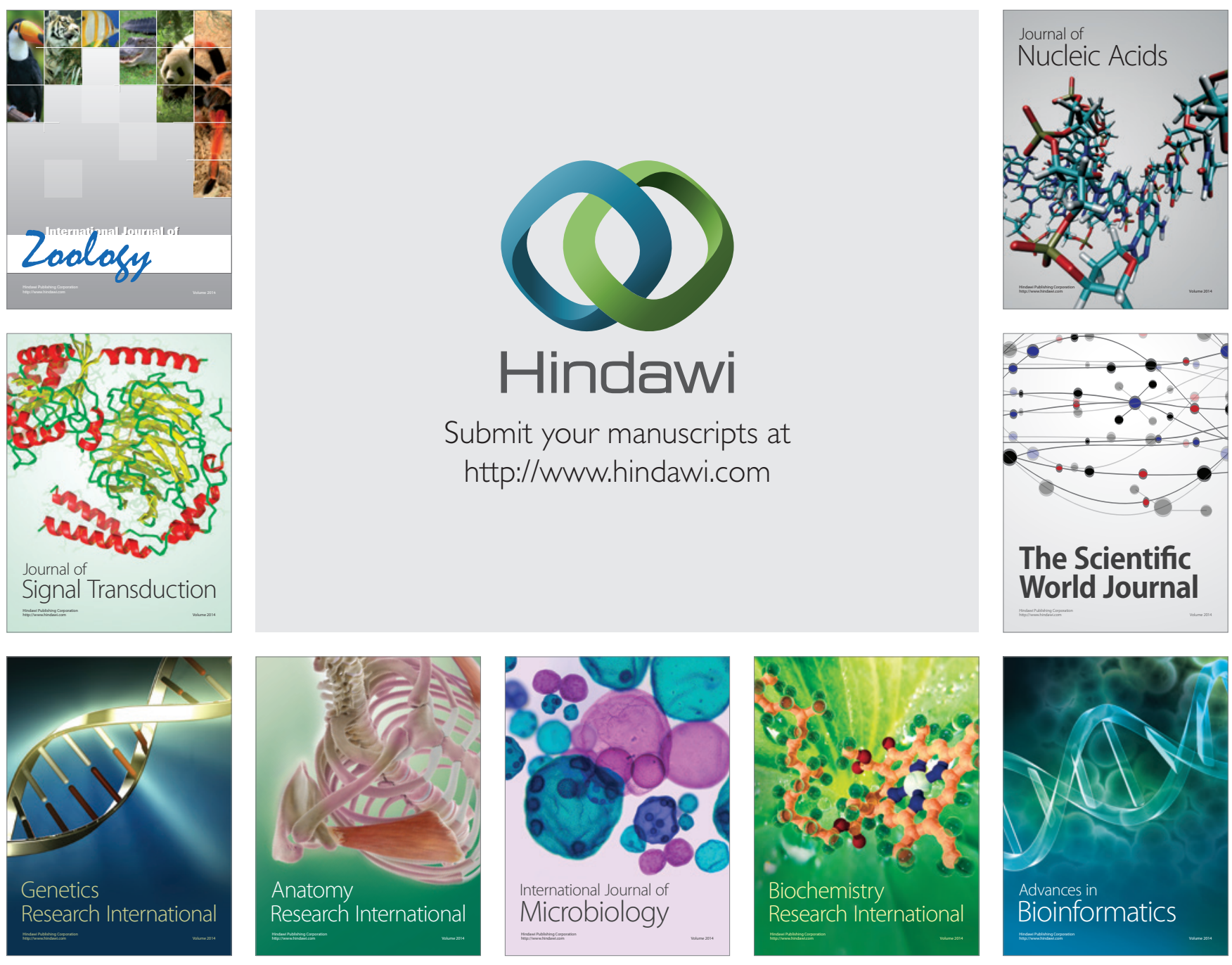

The Scientific World Journal
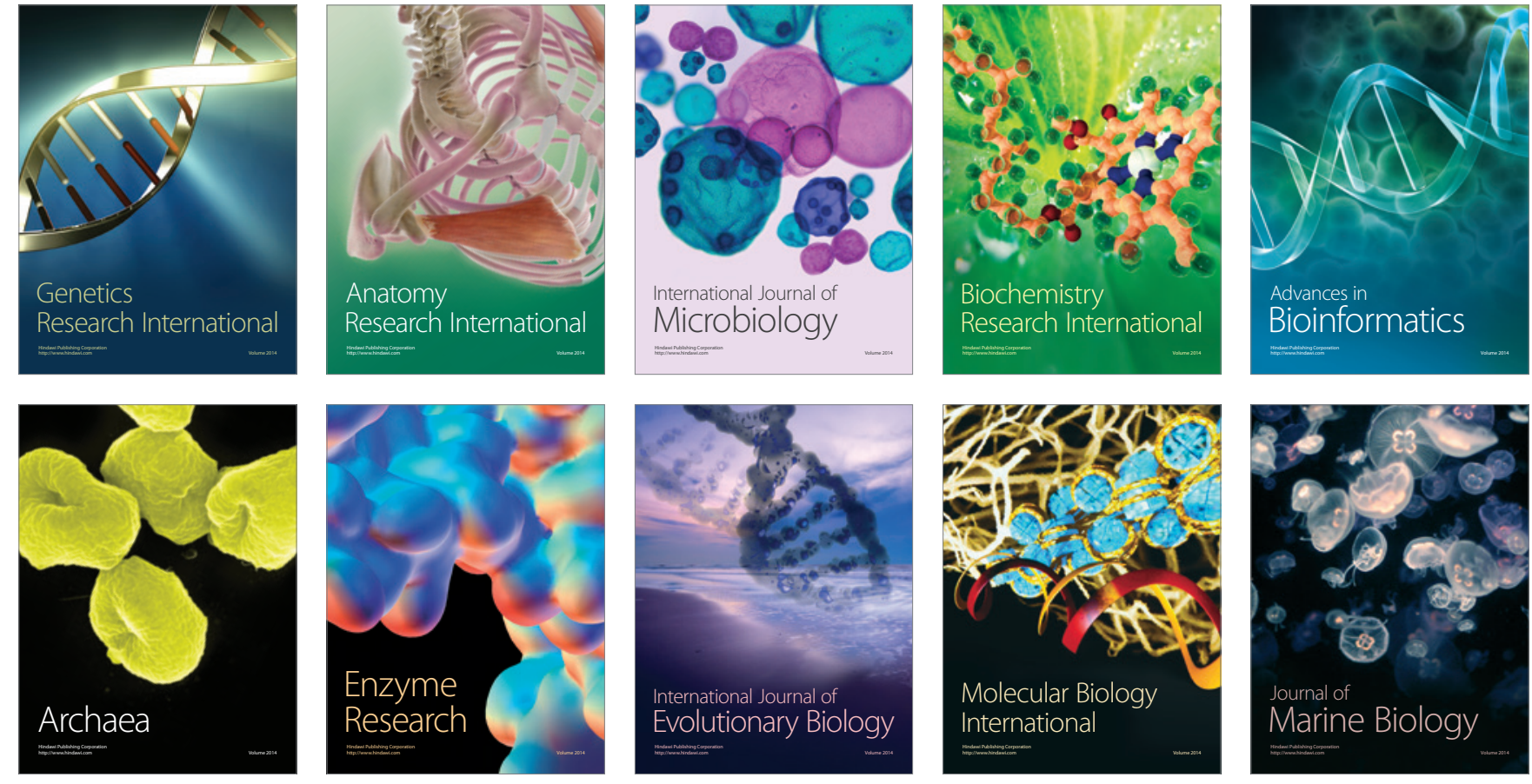